\title{
Selected International Aspects of Fundamental Tax Reform Proposals
}

\section{Citation}

Stephen E. Shay \& Victoria P. Summers, Selected International Aspects of Fundamental Tax Reform Proposals, 51 U. Miami L. Rev. 1029 (1997).

\section{Permanent link}

http://nrs.harvard.edu/urn-3:HUL.InstRepos:26506308

\section{Terms of Use}

This article was downloaded from Harvard University's DASH repository, and is made available under the terms and conditions applicable to Other Posted Material, as set forth at http:// nrs.harvard.edu/urn-3:HUL.InstRepos:dash.current.terms-of-use\#LAA

\section{Share Your Story}

The Harvard community has made this article openly available.

Please share how this access benefits you. Submit a story.

\section{Accessibility}




\title{
Selected International Aspects of Fundamental Tax Reform Proposals*
}

\author{
Stephen E. Shay \\ VICTORIA P. SUMMERs**
}

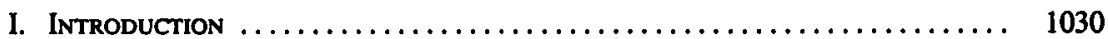

II. OVerview of Consumption TaXes $\ldots \ldots \ldots \ldots \ldots \ldots \ldots \ldots \ldots \ldots \ldots \ldots, 1032$

A. The Consumption Base Versus the Income Base, and Paradigms for

Taxation ........................................ 1032

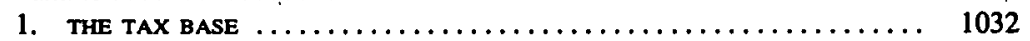

2. MODELS FOR TAXING THE CONSUMPTION BASE ............... 1034

3. CROSS-BORDER IMPLICATIONS AND INTERNATIONAL PRACTICE ........ 1037

B. Intermational Aspects of Tax Reform Proposals ................ 1040

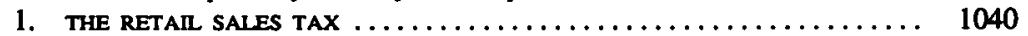

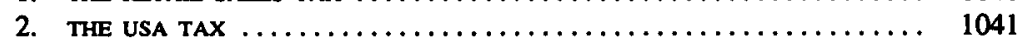

a. Business Tax................................ 1041

b. Individual Tax ............................... 1043

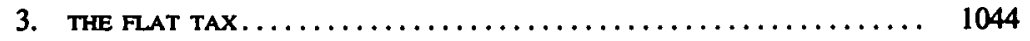

a. Business Tax................................ 1044

b. Individual Tax ............................. 1045

III. Taxation of Cross-Border Activity: Origin- Versus Destination-Based

TAXES ........................................... 1046

A. Border Tax Adjustments .............................. 1046

B. Effects on Trade .................................... 1046

C. International Practice ................................ 1047

D. Consistency with the GATT ........................... 1048

1. DIRECT VerSUS INDIRECT TAXES $\ldots \ldots \ldots \ldots \ldots \ldots \ldots \ldots \ldots, 1050$

2. IMPOSSIBLITY OF EXCESS REBATES OF TAX ............... 1051

3. ANALYSIS OF GATT APPLICATION TO THE TAX REFORM PROPOSALS ..... 1051

E. Conclusions ........................................ 1054

F. Overview of Tax Reform Proposals and GATT Consistency .......... 1056

IV. Treatment of Cross-Border Services in General and Financial

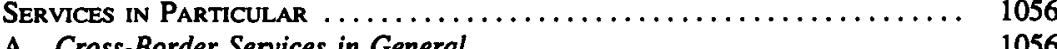

A. Cross-Border Services in General ......................... 1056

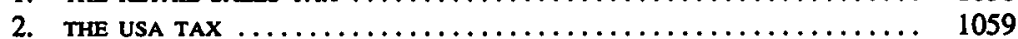

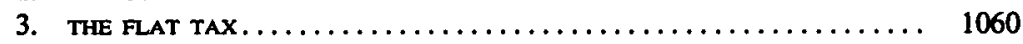

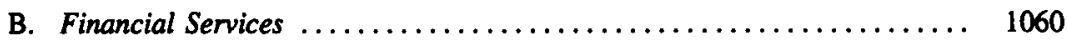

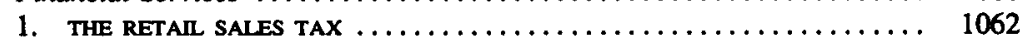

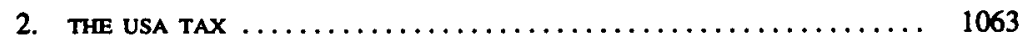

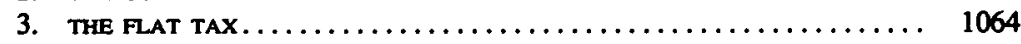

* An earlier version of this paper was prepared for the Tax Systems Task Force of the American Bar Association Section of Taxation, chaired by John S. Nolan. The authors benefitted from the discussions of the fundamental tax reform proposals among the members of the Task Force, especially the comments of Michael Graetz, from comments on earlier drafts by Dan Halperin, Peter Merrill and Phil West, and from discussion with Reuven Avi-Yonah.

** Stephen Shay is a partner with Ropes \& Gray in Boston. Victoria Summers is a member of the staff of the Fiscal Affairs Department of the International Monetary Fund in Washington, D.C. 


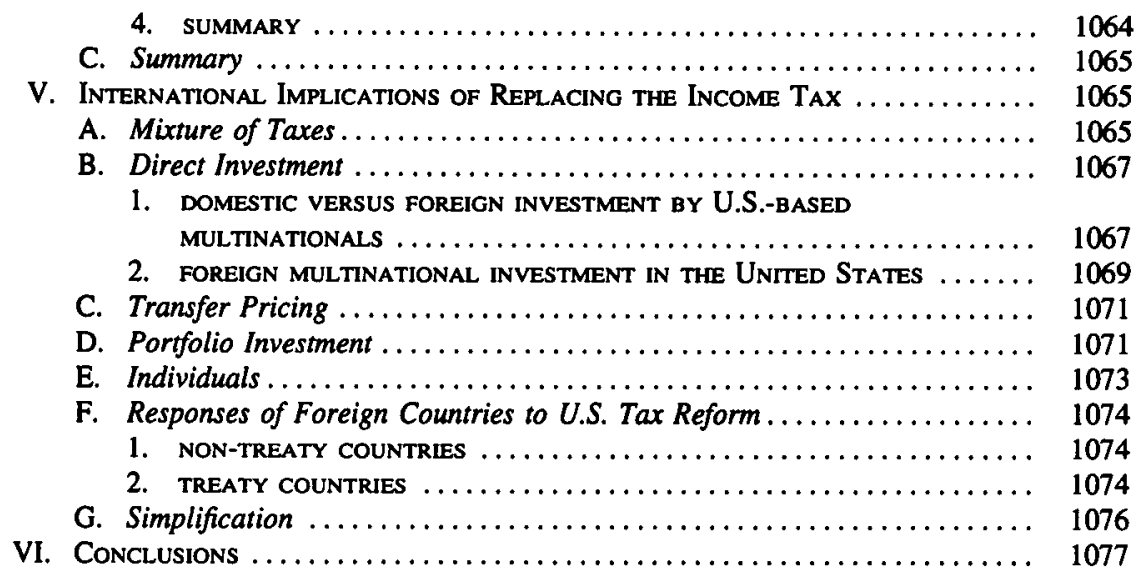

\section{INTRODUCTION}

Over the past several years, there have been a series of proposals to replace the U.S. income tax. The 1996 presidential primaries saw one major candidate, Steve Forbes, espouse the virtues of a flat tax. Another candidate, Senator Richard Lugar, favored a national retail sales tax. A year earlier, Senators Nunn and Domenici introduced their "Unlimited Savings Account" tax. Each of these proposals involves substituting a consumption-based tax for the current income tax.

Proponents of fundamental tax reform generally hope that shifting to a consumption tax base will bring about increased savings and investment and will simplify compliance and enforcement. ${ }^{1}$ Except for an occasional obligatory bow to the assertedly positive effects of these reforms on U.S. "international competitiveness," the public debate about tax reform rarely addresses international implications of the tax reform proposals. Yet these proposals would dramatically alter the international as well as the domestic tax landscape. Moreover, the open nature of the U.S. economy would fundamentally affect any impact of the tax reform.

This paper evaluates selected international aspects of three leading fundamental tax reform proposals; the Schaefer-Tauzin-Chrysler national retail sales $\operatorname{tax}^{2}$ the Nunn-Domenici "Unlimited Savings Account" tax (the "USA" tax), ${ }^{3}$ and the Armey-Shelby "flat tax" (the "Flat Tax"). ${ }^{4}$ A threshold problem is simply to understand how these

1. See James R. Hines $\mathbf{J}_{\mathbf{R} .,}$ Fundamental Tax Reform in an International Setting, in Economic Effects of Fundamental Tax Reform 465, 465 (Henry J. Aaron and William G. Gale eds., 1996).

2. National Retail Sales Act of 1996, H.R. 3039, 104th Cong. (1996).

3. USA Tax Act of 1995, S. 722, 104th Cong. (1995).

4. Freedom and Fairness Restoration Act of 1995, H.R. 2060, 104th Cong. (1995); S. 1050, 104th Cong. (1995). 
three proposals work, both as taxes generally and with respect to crossborder transactions in particular. In order to understand the effects of each of the three proposals, Part II begins with a discussion of consumption as a tax base and the usual approaches to taxing consumption at the business or personal level, as well as the usual approach to determining the geographic reach of the tax. Each of the three proposals is then described, with particular reference to its treatment of cross-border activity.

Part III considers decisions made in the proposals to tax on a destination or origin basis, and compares the forms of consumption taxes proposed to the standard credit-invoice method value-added tax ("VAT") adopted by most other developed countries. The differences between these three proposals and the internationally accepted creditinvoice method VAT have ramifications affecting interaction with the VATs of other countries. Part III also evaluates differences in the approaches taken under the three tax reform proposals with respect to the GATT rules proscribing export subsidies for sales of goods, as well as the advantages and disadvantages of origin- or destination-based taxes.

Part IV discusses the problems associated with consumption taxation of cross-border services generally, as well as taxation of financial services. This discussion identifies some of the practical problems of a consumption tax in an international environment.

Part V considers the international implications of replacing the federal income tax, including in particular the interaction of a reformed U.S. system with other countries' tax systems. In this section, and throughout the paper, it must be remembered that we are examining a consumption tax, not an income tax. Thus, the principal implications of Part V relate to the proposals' expressed objective that the United States have no income tax. The resulting "mix" of income and consumption taxes (i.e., all consumption and no income taxes) would be different from that of any other major developed country. We also consider the implications of such a dramatic change in the international tax landscape for and likely "first order" responses by U.S. and foreign investors and foreign governments.

The principal objective of this paper is to explain and to help the reader achieve some understanding of the three tax reform proposals as they would apply to international transactions. Where possible, the proposals are evaluated using the tax policy criteria of impact on economic efficiency, equity in distribution of tax burden, and the administrative 
burden of compliance with and enforcement of the tax..$^{5}$ As tax lawyers, not economists, any economic observations are based on our attempts to understand and apply the relevant economic principles.

Finally, the proposals are discussed as they have been proposed. There is no attempt to evaluate the likelihood of modifications to the proposals, or to predict the ultimate shape of any consumption tax regime which might be adopted.

\section{Overview of Consumption Taxes}

\section{A. The Consumption Base Versus the Income Base, and Paradigms for Taxation \\ 1. THE TAX BASE ${ }^{6}$}

As discussed below, each of the tax reform proposals is, in substance, a consumption tax. It is helpful as a threshold matter to review the difference between an income and a consumption tax base.

The consumption tax base can be derived from the classic definition of income from the "uses" side: an individual's income for each period is the sum total of what he does with the resources at his disposal. This is equal to the individual's consumption plus the change, positive or negative, in his net worth. Under a consumption tax, the change in net worth is untaxed, and only the amount spent on consumption in the period is subject to the tax. Any increase in net worth that is saved during the period is not taxed currently. Thus, the consumption tax base equals total income less net savings, or plus net dissavings. What is left after accounting for net savings or dissavings is consumption.

When examined from the source-of-income side, the fundamental distinction between a broad-based general income tax and a broad-based general consumption tax is that the former imposes a tax on income derived from the return to capital, while the latter does not. In other

5. In any tax system, there is tension among the goals of minimizing the negative effects of taxation on economic efficiency, maintaining or achieving an equitable distribution of the tax burden, and minimizing compliance and enforcement costs. Substantial economics literature has been published concerning the effect of taxation on production efficiency and the social welfare implications of taxation. Only recently has there been increased focus on the resource costs of alternative tax systems. See, e.g., Joel Slemrod, "Optimal Taxation and Optimal Tax Systems, $4 \mathrm{~J}$. Econ. Persp. 157 (1990); Joel Slemrod, Which Is the Simplest Tax System of Them All?, in Economic EfFects of Fundamental Tax Reform 355 (Henry J. Aaron and William G. Gale eds., 1996).

6. For an extremely cogent discussion of this topic, see STAfF of Joint CoMm. on Taxation, 104th Cong., Description and Analysis of Proposals to Replace the Federal InCOME TAX, [1995] 82 Stand. Fed. Tax Rep. (CCH) No. 29 (June 15, 1995) [hereinafter Jornt Comm., Proposals to Replace the Income Tax]. See also David F. Bradford, Blueprints FOR BASIC TAX REForm (2d ed., 1984). 
words, a person's consumption will equal total income less income from investment.

Why is taxing the amount expended on consumption equivalent to exempting from current tax the return to capital? This equivalence exists because-assuming the tax rate remains the same over timededucting amounts not spent on consumption (i.e., amounts saved and invested) from the tax base, and taxing the full amount (principal plus interest) withdrawn from savings when it is later consumed (the "cashflow" method of taxation), yields the taxpayer the same amount of total after-tax resources in present value terms as taxing all "income" prior to savings, but not imposing a tax on the total amount withdrawn (including all interest earned) when the savings are later consumed (the "yieldexemption" method). ${ }^{7}$ This is more easily illustrated by an example:

Assume that, in a two-period model: (i) an individual earns $\$ 100$ and invests the entire amount, earning a $10 \%$ return; (ii) all investments earn the same returns; and (iii) the individual is subject to a $40 \%$ tax rate that remains constant in the two periods. Under the "cash-flow" savings deduction model, the individual pays no tax in year one because his $\$ 100$ in income is offset by a deduction for the $\$ 100$ saved and invested. At the end of year two, the individual withdraws the $\$ 110$ for consumption, pays tax of $\$ 44$, and has an after-tax balance of $\$ 66$ to spend. Under the "yield-exemption" method, the individual would pay a tax of $\$ 40$ at the end of year one, invest the $\$ 60$, and have $\$ 66$ to spend at the end of year two.

If, under the assumptions described, a consumption tax effectively "exempts" returns to capital, what is taxed? Under a consumption tax like that described, only returns to labor are taxed. If the assumptions of are relaxed, and the investment earns a "supra normal" return (i.e., above the expected discounted cash flow), the supra normal return would be taxed under the cash-flow method, but would be exempt under the yield-exemption method. ${ }^{8}$

Several issues become apparent from this brief discussion. For one, there theoretically must be several ways to measure the consumption

7. As noted, this equivalence depends on the tax rate being constant over time. Further, the equivalence holds only with respect to so-called "normal" return to capital, that is, the rate of return that would be earned on the tax saved with respect to untaxed, invested income under a cash-flow method.

8. Under the cash-flow method, if a specific investment produces a higher return than the "normal" cost of capital, that excess return would in effect be taxed as the initial savings from the deduction, as the investment will have been at the normal rate of return. Conversely, under the "yield exemption" method, all returns to after-tax invested income will by definition always be exempt. See Alvin C. Warren, Jr., How Much Capital Income Taxed Under an Income Tax is Exempt Under a Cash-Flow Tax? (Nov. 1996, unpublished manuscript, on file with the University of Miami Law Review). 
base and impose a tax on it. Most significantly for this discussion, when taxing consumption in an open economy, as when taxing income, the geographic scope of "consumption" to be taxed must be defined. While not definitive, the form of the tax adopted may suggest different answers to the question of geographic scope.

\section{MODELS FOR TAXING THE CONSUMPTION BASE}

The principal models for taxing consumption vary according to whether, inter alia, (i) the business or the consumer determine and collect the tax, and (ii) the tax is determined on an accounts or separate transaction basis. At one extreme, a perfect retail sales tax, which imposes tax on the value of each purchase of goods and services acquired by a final consumer but not on goods acquired for use in production, would by definition tax all consumption in the economy, as the tax measures such consumption directly. ${ }^{9}$ Theoretically, such a tax could be levied on the consumer, by requiring the consumer to report and document all purchases in a given period. In practice, however, such consumption/sales taxes are levied on the businesses selling the goods and services.

Collection by sellers places the burden of complying with the tax on fewer persons and on those persons who have independent reasons to maintain records of sales. Thus, significant resource savings, in both compliance and enforcement costs, should result from having businesses collect a retail sales tax. One of the most vexing problems with a retail sales tax collected by sellers, however, is in determining whether products are being purchased for final consumption, for use in production of other goods and services, or for resale. To the extent that products to be used for production or resale are not exempted from the tax, the tax will "cascade," and the total tax burden applicable to different items will vary randomly, introducing economic inefficiencies.

At the other extreme, consumption could be measured indirectly, by subtracting each consuming individual's change in net worth (i.e., his or her current savings) from total income for the tax period. This gives rise to a "consumed income tax," which is a "direct" tax in that it is levied on the individual intended to bear the tax, rather than on an inter-

9. A retail sales tax is one that is imposed on the retail sales price of taxable goods or services. As the name suggests, the tax is imposed on the consumer and collected by the seller at the time of sale. Persons other than consumers (i.e., businesses) may be exempt from the tax if the goods or services are acquired for resale or for use in manufacture, fabrication or processing of property for resale. As applied by the individual states, a sales tax generally is not applied to goods shipped outside the taxing jurisdiction, that is, the sales tax is border-tax adjusted. Many states impose a "use" tax with respect to property sold for consumption in the state from outside the state. 
mediary player, as in the case of the retail sales tax. This system would have the potential advantage, or at least the feature, that it could be imposed at progressive rates varying with the individual's total amount of consumption during a given period, and with family or other circumstances, much like the current income tax. With this potential "equity" advantage, however, comes the increased compliance and enforcement burden of having every consumer or consuming household determine, file and pay the tax. ${ }^{10}$

Between the extremes of a retail sales tax and a personal consumption tax lies the existing international model of the VAT, which is an indirect tax on the value of consumption collected by business at each stage of production, rather than all at once at the stage of final sale. Virtually all existing VATs are designed more or less as "credit-invoice VATs" after the European model. ${ }^{11}$ In this system, tax is collected by every taxpayer business by applying the relevant rate to the good or service sold. The taxpayer's net liability for the period is the total of all taxes on each transaction (the tax is "transactions-based"), less all VAT paid during the period on purchases of taxable business inputs, as evidenced by invoices received from suppliers. ${ }^{12}$ The full, immediate credit for all capital investments by the business (i.e., "cash-flow taxation") causes existing VATs to be consumption-based. ${ }^{13}$

10. Although income taxation presents difficult issues concerning the timing of income recognition and determination of gains, substantial amounts of individual income are reported by third-party payors of wages, interest, dividends and proceeds from the sale of securities under the current income tax. See I.R.C. \$§ 3402, 6049, 6042, 6045 (1994). For discussions of issues raised by a direct consumption tax on individuals, see George R. Zodrow \& Charles E. McLure, Jr., Implementing Direct Consumption Taxes in Developing Countries, 46 TAX L. Rev. 405 (1991); Michael J. Graetz, Implementing a Progressive Consumption Tax, 92 HARv. L. Rev. 1575 (1979).

11. See Joint Comm., Proposals To Replace the Income Tax, supra note 6, at 19.

12. This tax was adopted throughout Europe in part because of the widespread and quantitatively important difficulties encountered there with cascading of the existing turnover taxes. A multi-stage VAT utilizing the credit-invoice method automatically eliminates cascading. In order to eliminate the taxes paid on exported products, those products are "zero-rated," that is, they are treated as taxable, but at a rate of zero. Therefore, no tax liability arises on export sales, but the taxes paid to suppliers on inputs to produce the exported products are creditable, just as if the sales were domestic. A taxpayer whose sales are solely for export, would thus have negative net tax liability in every period, and would receive refunds of all taxes paid on its inputs. As discussed below, zero-rating is not a GATT-prohibited subsidy. It simply removes all domestic VAT included in the product price prior to export. Reference to "exempt" sales, as opposed to "zero-rated" sales, usually means that the seller does not receive a refund of the VAT on inputs. The VAT on inputs from the product price is retained; in effect, all stages of production except for the final export are subject to tax.

13. It is theoretically possible to have an "income-based VAT," operating on the same mechanism but only granting tax credits for inputs in the same manner as under the existing income tax-that is, capital investment is credited over an economic depreciation schedule, rather than immediately. Some VATs in transitional and developing countries, in fact do not grant full, 
The other main possibility for designing such a multi-stage VAT is a "subtractive-method VAT."14 Under this system, sometimes referred to as "accounts-based," business purchases are subtracted from gross sales for the period, and the net result is multiplied by the tax rate. ${ }^{15}$

A range of "pure" consumption tax alternatives is described in the following table.

\begin{tabular}{|l|l|l|}
\hline Type of Tax & $\begin{array}{l}\text { Collected by/ } \\
\text { Transaction or } \\
\text { Account-Based }\end{array}$ & Description \\
\hline Retail sales tax & $\begin{array}{l}\text { Business/ } \\
\text { Transaction }\end{array}$ & Tax imposed on each retail purchase \\
\hline Credit-invoice VAT & $\begin{array}{l}\text { Business/ } \\
\text { Transaction }\end{array}$ & $\begin{array}{l}\text { Tax imposed on each sale with a credit } \\
\text { for purchases of goods or services (but } \\
\text { not wages) used in the production of } \\
\text { taxable goods or services }\end{array}$ \\
\hline $\begin{array}{l}\text { Subtractive-method } \\
\text { VAT }\end{array}$ & Business/Account & $\begin{array}{l}\text { Tax imposed on difference between } \\
\text { sales and payments for inputs used in } \\
\text { production (other than wages) in the } \\
\text { period }\end{array}$ \\
\hline $\begin{array}{l}\text { Cash-flow personal } \\
\text { consumption tax }\end{array}$ & Individual/Account & $\begin{array}{l}\text { Tax imposed on difference between } \\
\text { individual's total income less net } \\
\text { savings }\end{array}$ \\
\hline $\begin{array}{l}\text { Yield-exemption } \\
\text { personal } \\
\text { consumption tax }\end{array}$ & Individual/Account & $\begin{array}{l}\text { Tax imposed on total income less } \\
\text { investment income }\end{array}$ \\
\hline
\end{tabular}

A further intermediate possibility between the retail sales tax and the consumed income tax, proposed in the U.S. tax reform debate, is a combination tax. Combination taxes are imposed in part on businesses which produce added value to products to be consumed, and in part on the ultimate consumer in the form of "direct" taxes. The proposed Flat Tax would tax (with modifications) the consumption base in the aggregate, by imposing a subtractive-method VAT at the business level but providing a deduction for wages. ${ }^{16}$ At the individual level the wages would be taxed under a consumed income tax. The proposed USA tax is a business-level VAT coupled with an individual-level consumed

immediate credit for capital asset purchases, and thus do not tax only the consumption base. See, e.g., Sullivan, Flat Taxes and Consumption Taxes: A Guide to the Debate, 30-31 (AICPA 1995).

14. The possibility of an "additive-method" VAT also exists. Under this method, each firm's tax base would be calculated directly by adding its wage bill to its profits before debt service for each tax period. See Joint Comm., Proposals to Replace the Income TaX, supra note 6, at 2021. This is similar to both the Michigan Single Business Tax and the methodology used for taxing financial services in Israel.

15. See id. at 20.

16. See Freedom and Fairness Restoration Act of 1995, H.R. 2060, 104th Cong. $\$ 101$ (1995) (to be codified at I.R.C. $\$ 11$ ). 
income tax (with modifications). ${ }^{17}$ In both cases, the reason for combining the indirect and direct tax features is to permit some progressivity in taxation at the individual level through use of a standard deduction, in the case of the Flat Tax, or graduated rates, in the case of the USA tax.

\section{CROSS-BORDER IMPLICATIONS AND INTERNATIONAL PRACTICE}

Under an income tax, a determination must be made whether to only tax income arising in the taxing country or also income derived from abroad. Similarly, under a consumption tax, a determination must be made whether to only tax domestic consumption (by residents and nonresidents, or residents only), or consumption abroad by domestic residents as well.

Existing consumption taxes, both at the state level and in other countries, are designed to tax all domestic consumption, and to exclude consumption abroad. They are therefore referred to as "destinationbased," meaning that taxation occurs at the rate applied by the country of consumption, which retains the revenue. Under the destination principle, exports are exempt and imports are taxed by imposing an import tax on goods at the border. ${ }^{18}$ The destination principle may be illustrated as it applies to a retail sales tax. When a consumer purchases a toy at the local toy store, the tax is imposed regardless of whether the consumer is a resident, a citizen, or a nonresident alien. On the other hand, no tax is imposed when the purchase is shipped outside the taxing jurisdiction. ${ }^{19}$ A credit-invoice method VAT is also destination-based: exports are not taxed, taxes imposed on inputs to an export are rebated to the exporter, and imports are taxed to the buyer. ${ }^{20}$ VAT is imposed on

17. See USA Tax Act of 1995, S. 722, 104th Cong. $\$ \S 101,301$ (1995).

18. See Harry Grubert \& T. Scott Newlon, The International Implications of Consumption Tax Proposals, 48 NAT'L TAX J. 619, 622-23 (Dec. 1995). A discussion of the mechanism by which the destination principle is applied in the European VATs and how it would be applied in the tax reform proposals appears below. The economic implications of this principle are discussed in Part III herein.

19. Under U.S. law, a separate issue is whether the seller is conducting business in the jurisdiction to which the good is shipped so as to incur liability for collection of a "use" or comparable consumption tax in that jurisdiction.

20. The mechanics of implementing a credit-invoice method destination-based VAT with respect to goods are relatively straightforward where effective border controls exist, as in the United States. The VAT on imports is collected at customs clearance, and goods are not cleared without payment. With respect to exports, documentation of actual export is also obtained through customs. This permits those items to be reported as taxed at a zero rate. All business inputs are creditable, regardless of whether goods are sold domestically (in taxable transactions) or exported (in taxable, albeit zero-rated, transactions). Alternative methods for implementing a destination-based tax are discussed in Part III. Presumably, under a subtractive tax such as the USA tax, the customs clearance mechanisms would apply in the same manner as in the existing 
domestically-consumed goods regardless of the consumer's residence, and all VAT embodied in exported goods is rebated to the exporter. These border tax adjustments and their effects on trade are discussed below.

A consumed income tax imposed on residents of the taxing country could also be designed to tax only consumption within the country, by permitting deductions for consumption expenditures abroad as well as for domestic and foreign savings. A direct consumed income tax that taxes domestic consumption by foreign individuals would be quite difficult to implement, unlike an indirect consumption tax collected by business. The foreign individual would have to determine what savings and income were attributed to the United States and file a U.S. return thereon.

An alternative approach would be one in which the producing country taxes at its own rates the added value of all its products sold for consumption or exported. This is referred to as an "origin-based" system because the tax is imposed at the place of production as opposed to the place of purchase. Imposing a domestic tax on exports and not on imports would implement an origin-based system, ${ }^{21}$ wherein the aggregate tax base is domestic consumption and net exports. ${ }^{22}$ Alternatively, a consumption tax could tax all consumption by residents and citizens, regardless of location. Although this would be at variance with current

credit-method VATs. The treatment of exported and imported services, discussed in Part IV, is more difficult.

21. Ensuring that the domestic tax is not imposed on imports under an origin-based system is not as straightforward as it sounds. When imports become part of domestic production or resale following arrival, a credit (in the credit-method tax) must be given for the imputed domestic tax burden. Otherwise, the full value of the import is subject to the domestic tax at the next stage of production. Implementing a tax which taxes exports, but fails to eliminate the tax on imports in this manner would actually be protectionist, unlike a full-destination based tax. See MarTIN Feldstein \& Paul Krugman, International Trade Effects of Value-Added Taxation, in TAXation in the Global Economy 263 (Assaf Razin \& Joel Slimrod eds., 1990). Similarly, in a subtractive tax, a deduction would have to be given for imported business inputs just as for domestic ones, as if the tax had been paid with respect to them. The proposed Flat Tax apparently does this, though detail is lacking.

Although it is frequently claimed that it is easier to implement an origin-based tax where there are no effective border controls, this is not necessarily true. See Baer et al., A Destination VAT for CIS Trade, 6 MOCT-MOST 87 (1996). Both methods require verification that a certain quantity of goods was exported or imported. Under the origin principle, however, since the applicable tax rate is not zero, exports must be valued, rather than just certified as exported. In the case of an export, it is more difficult to ensure than with a domestic sale that the stated price is what was actually paid, because the purchaser will not be seeking to claim a credit from the domestic tax authorities. In order to ensure that only the actual value of imports is excluded from the final cost of products, it is also necessary to value imports accurately. Under the destination method, on the other hand, any under-taxation of intermediate goods should be made up by inclusion of their full value, without the full credit, at the next stage of production.

22. See Grubert \& Newlon, supra note 18, at 623. 
world practice, if desired it would be most easy to implement using a personal consumed income tax.

Before reviewing the tax reform proposals under consideration, it may be helpful to identify some of the principal issues to be faced in deciding among the previously-described alternative approaches to taxing consumption. An initial issue is whether to impose the tax at the business or the individual level. Existing international practice is to impose the tax at the business level through a credit-invoice VAT. Currently, however, essentially every foreign country also imposes an income tax. Thus, equity or distributive objectives may be achieved through the income tax. As discussed below, two of the tax reform proposals adopt a "hybrid" approach that imposes tax at both the business and the individual level. This approach appears directly related to the proposal to repeal the income tax.

As a conceptual matter, a tax imposed at the business level may be imposed on a transactions basis or on an accounts basis. ${ }^{23}$ Again, current international practice is to impose the tax on a transactions basis using a credit-invoice VAT. Although the retail sales tax is imposed on a transactions basis, the other two reform proposals under consideration employ an accounts-based subtractive-method VAT. A major reason for adopting this approach is to make it more difficult to exempt individual products from the tax or to adopt multiple rates, as is common under the credit-invoice VAT. Exempting of various goods and using multiple rates is a significant sources of inefficiency and administrative burden with a VAT system. In the absence of an income tax, there would likely be extraordinary pressure to adopt exemptions or reduced rates for foodstuffs and products consumed by low-income families. Proponents of the subtractive-method VAT proposals hope that the practical difficulties of implementing such exemptions will force redistributive relief to be implemented exclusively through the individual-level tax linked to each such proposal. The objective is to minimize inefficiency and administrative burden caused by the distortions and complexity resulting from exemptions and use of multiple rates. ${ }^{24}$

Finally, none of the three proposals taxes activity outside the United States. Two are destination-based and one is origin-based. The origin-based tax reform proposal, the Flat Tax, integrates the business and individual taxes by allowing a deduction for compensation at the

23. As discussed below, a credit-invoice VAT is implemented in practice using the business account books; as discussed here, a tax imposed on an accounts basis relates to the design of the tax rather than administration of the tax.

24. See David G. Raboy, Consumption Tax Preferential Treatment: Poor Cure for Regressivity, 72 TAX Notes 901, 903-05 (Aug. 12, 1996); William J. Turnier, Designing an Efficient Value Added Tax, 39 TAX L. REv. 435 (1984). 
business level. ${ }^{25}$ The business-level tax, taken alone, would not be an "indirect" tax on value added and arguably would not permit an exemption on exports under the GATT rules. ${ }^{26}$ Accordingly, the tax is imposed on an origin basis.

\section{B. International Aspects of Tax Reform Proposals}

The three tax reform proposals will be reviewed with the foregoing basic design issues in mind. Note that all of the proposals are intended to raise the same amount of revenue as under current law.

\section{THE RETAIL SALES TAX}

The retail sales tax would impose a $15 \%$ tax on gross payments for use, consumption, or enjoyment in the United States of any property or service, whether produced or rendered in the United States or elsewhere. ${ }^{27}$ In general, the tax would be collected and remitted by the seller. ${ }^{28}$ The tax on property or services purchased outside the United States for use, consumption, or enjoyment in the United States would be payable by the purchaser. ${ }^{29}$ The tax would be payable by the seller upon receipt of payment, even if payment were made in installments, unless the seller elected to use an accrual method of accounting for the tax.

Exemptions would apply to property or services: (1) purchased for resale; (2) purchased to produce other taxable property or services; (3) exported for use, consumption, or enjoyment outside the United States; ${ }^{30}$ or (4) below certain de minimis levels. ${ }^{31}$ Special rules would apply to property or services purchased for a dual purpose (i.e., both a taxable and a tax-exempt purpose). As discussed below, special rules would also apply to tax financial intermediation services.

The retail sales tax, then, would be imposed on a destination basis, and no export tax would be collected. The tax would be collected by the selling business, except for imported goods, in which case the consuming purchaser would be responsible for the tax. As a practical matter, the tax on imports would be difficult to collect and enforce.

25. See Freedom and Fairness Restoration Act of 1995, H.R. 2060, 104th Cong. $\$ 101$ (1995);

S. 1050, 104th Cong. \& 102 (1995).

26. The GATT rules may not in fact be clear on this point. See discussion infra Part III.

27. See H.R. 3039, 104th Cong. § 4(a) (1996) (to be codified at I.R.C. § 1(a)).

28. See id. (to be codified at I.R.C. \& I(c)(1)).

29. See id. (to be codified at I.R.C. \& I(c)(2)). The tax imposed on imported property would be in addition to any import duties. See id. (to be codified at I.R.C. $\S 1(b)$ ).

30. See id. (to be codified at I.R.C. \& 2(a)(1)-(3)).

31. See id. (to be codified at I.R.C. \& 2(b)). 


\section{THE USA TAX}

The USA tax is a "hybrid" consumption tax, imposed in part on businesses producing added value and in part on individuals. The individual tax would be measured by current consumption under a variant of a "cash-flow" personal consumption tax. Businesses would be subject to a flat-rate subtractive-method destination-based VAT. U.S. citizens and resident individuals would be subject to a graduated-rate personal consumption tax. The elements of the business and individual taxes as they relate to cross-border issues are described below.

\section{a. Business Tax}

Taxation of U.S. and not foreign business activity. The USA tax on business activity would be imposed at a rate of $11 \%$ on any business entity's gross profits earned from engaging in business in the United States. ${ }^{32}$ A "business entity" would include a partnership, a trust, an individual engaged in business as a proprietor, and a corporation, whether domestic or foreign. ${ }^{33}$

Receipts. Gross profits would be determined by subtracting deductible amounts from taxable receipts. ${ }^{34}$ "Taxable receipts" would include receipts from the sale or use of property and from the performance of services in the United States. ${ }^{35}$ Taxable receipts would not include income from capital, such as interest and dividend income. ${ }^{36}$ Similarly, interest and dividend payments and the costs of acquiring a savings asset would not be deductible. ${ }^{37}$

Deductions. Deductible amounts would include costs of business purchases for use in business activity in the United States. ${ }^{38}$ In other words, current expensing for capital investment would be allowed. Imported products or services for use or consumption in the United States would be a deductible business purchase if used in a U.S. business activity. ${ }^{39}$ Payments for compensation would not be deductible, but a credit would be allowed for payroll tax..$^{40}$ Deductible payments would not include cost of property purchased or services performed outside the

32. See S. 722, 104th Cong. $\S 1$ (B) (1995) (to be codified at I.R.C. $\S 201$ (B)).

33. See id. (to be codified at I.R.C. $\$ 206($ a)).

34. See id. (to be codified at I.R.C. § 202).

35. See id. (to be codified at I.R.C. $\$ 203$ ).

36. See id. (to be codified at I.R.C. $\$ 203(\mathrm{e})$ ).

37. See id. (to be codified at I.R.C. $\$ 204$ ).

38. See id. (to be codified at I.R.C. $\$ \S 204,205(a)$ ). Purchases would be deductible even if the goods were sold outside the United States and, as discussed below, the income were exempt.

39. See S. 722, (to be codified at I.R.C. $\$ 266(a)$ ).

40. See id. (to be codified at I.R.C. \& 205(a)(3)). 
United States. ${ }^{41}$ Domestic expenditures benefiting foreign, export, or domestic business activity, such as research and development costs and headquarters management costs, would be absorbed entirely against U.S. receipts.

Taxation of exports and imports. The USA business tax would be imposed on a destination basis, exempting exports and taxing imports. ${ }^{42}$ By excluding exports from taxable receipts, the USA business tax in essence would provide a "border tax adjustment" for property or services exported for use or consumption outside the United States. ${ }^{43}$ Deductions attributable to export income, however, give rise to a refund only to the extent they offset taxable gross profit.

An import tax would be imposed at the same $11 \%$ rate as the business tax on the customs value of property imported for consumption, use, or warehousing, and on the cost of imported services. ${ }^{44}$ The import tax would be imposed on the person bringing the property into the United States ${ }^{45}$ or in the case of services, on the person receiving the services. ${ }^{46}$ A royalty paid to a non-U.S. person for a business purchase of intangible property would presumably be subject to the import tax.

Source rules. The source of a sale of property would be based on where it was to be used or consumed. ${ }^{47}$ Property sold for use or consumption outside the United States would be treated as exported.

The general services source rule would provide that services be attributed to the place of performance. The general rule would be modified, however, if the "benefit" of a cross-border service were realized by a purchaser solely within or without the United States. ${ }^{48} \mathrm{~A}$ business would be treated as exporting a service, income from which would be excluded from taxable receipts, if the benefit of the service would be realized outside the United States and solely in connection with the activities of the purchaser outside the United States. ${ }^{49}$ A service would be considered imported if its benefit were realized in the United States solely by a business purchaser in connection with U.S. business

41. See id. (to be codified at I.R.C. $\$ 205(a)(3)(D)-(E))$.

42. See id. (to be codified at I.R.C. $\$ \S 265-267$ ).

43. See id. (to be codified at I.R.C. $\S 265($ a)).

44. See id. (to be codified at I.R.C. $\$ \S 286-287$ ).

45. See id. (to be codified at I.R.C. \& 286(b)).

46. See id. (to be codified at I.R.C. $\$ 287(\mathrm{~b})$ ).

47. See id. (to be codified at I.R.C. \& 265(a)).

48. See id. (to be codified at I.R.C. $\$ 267$ ).

49. See id. (to be codified at I.R.C. $\$ 267(\mathrm{c})$ ). In order for the provision of a service to come within the USA tax net, it would have to be performed in the United States. If it was not, no deduction would be available for performance costs incurred. Whether or not the receipts would be taxable would depend upon whether the service was "exported" or used domestically. 
activities. $^{50}$

Communications services would be treated as provided at the communication's point of origin, and would not be treated as exported or imported. ${ }^{51}$ Special rules would apply to determine when receipts from transportation, insurance, and banking services were deemed exported. ${ }^{52}$

\section{b. Individual Tax}

Taxation of worldwide income of citizens and residents. Citizens and resident individuals would be subject to the USA tax on their worldwide adjusted gross income, defined as current year gross income and deferred income less alimony and child support deductions and the "Unlimited Savings Allowance," less deductions. ${ }^{53}$

The marginal tax rate for individuals would quickly reach $40 \%$ (at $\$ 24,000$ for married individuals filing jointly). ${ }^{54}$ Distributions from business entities, such as interest and dividends, would be included in gross income. ${ }^{55}$ Deductions would be limited to personal and dependency and family living allowances and homeowner, education, philanthropic transfer, and transition basis deductions. ${ }^{56}$ The consumption feature of the USA tax is the allowance of a deduction to individuals for net savings, that is, generally, investment in savings assets less proceeds of dissavings. ${ }^{57}$ Under the USA tax, "savings assets" include investments in foreign as well as domestic stocks, bonds, securities, deposits, and business entities. ${ }^{58}$

Foreign income. The current $\$ 70,000$ exclusion for a U.S. citizen or resident living abroad would continue to apply under the USA tax. ${ }^{59}$ Under rules prescribed by the Secretary of the Treasury, a foreign tax

50. See id. (to be codified at I.R.C. $\$ 267($ b). If a service provider performed services both within and without the United States, a business entity purchasing the services would be required to follow the source of services indicated on the invoice. See id. (to be codified at I.R.C. $\$ 267(d)(1))$. In the absence of an invoice, the services would be treated as provided in the location to which payment was sent, and the service provider would treat as taxable any payment received in the United States for services. See id. (to be codified at I.R.C. $§ 267$ (d)).

51. See id. (to be codified at I.R.C. \& 269).

52. See id. (to be codified at I.R.C. $\$ \S 268,270,271$ ).

53. See id. (to be codified at I.R.C. $\$ \S 1,2(\mathrm{~b})$ ).

54. See id. (to be codified at I.R.C. \& 15(a)).

55. See id. (to be codified at I.R.C. \& 3(a)(3)).

56. See id. (to be codified at I.R.C. \$\$ 5-11).

57. See id. (to be codified at I.R.C. $\$$ 50). Certain mysteries of the application of the "Unlimited Savings Allowance" in the USA tax are unraveled in Alvin C. Warren, Jr., The Proposal for an Unlimited Savings Allowance, 68 TAX Notes 1103 (Aug. 28, 1995). For purposes of this paper, it is sufficient to generalize that taxpayers subject to the USA tax would be allowed a deduction for net savings.

58. See USA Tax Act of 1995, S. 722, 104th Cong. (1995) (to be codified at I.R.C. $\$$ 53(b)).

59. See id. (to be codified at I.R.C. $\S 4(\mathrm{a})(8)$ ). Deductible net savings would not be reduced by this source of nontaxable earnings (as they would be for tax-exempt interest). 
credit would be allowed for foreign taxes imposed on amounts included in gross income. ${ }^{60}$

Source-based taxation of nonresident alien nonbusiness income. Nonresident aliens not engaged in a U.S. business would not be subject to the USA tax. ${ }^{61}$ Instead, they would be taxed on nonbusiness income on a source basis, much as under current law. ${ }^{62}$ A $30 \%$ tax would be imposed on the gross amount of U.S.-source interest (other than portfolio interest), dividends, rents, salaries, compensations, and other fixed or determinable annual or periodic income. ${ }^{63}$ As under the current income tax, the $30 \%$ tax would be collected by withholding under the same rules as currently apply. ${ }^{64}$ A nonresident alien's gains from the sale of nonbusiness assets would continue to be excluded from gross income. ${ }^{65}$

The USA tax proposal expresses a policy preference for an international system in which all nonbusiness income is exempt from source taxation. Pending change to this new international system, however: (1) treaties with respect to source taxation of nonbusiness income of nonresidents would continue to be respected; ${ }^{66}$ and (2) exemption from U.S. taxation at source would also be allowed with respect to any resident of a foreign country that exempts U.S. citizens and residents from tax at source, provided that the foreign country is a party to a tax informationsharing agreement with the United States. ${ }^{67}$

\section{THE FLAT TAX}

The Flat Tax would impose a single-rate tax on business and individual tax bases, as described below.

\section{a. Business Tax}

Taxation of U.S. business activity (including exports). The Flat Tax on businesses would apply to individuals, partnerships, corporations, and any other entity or person, foreign or domestic, carrying on business in the United States. ${ }^{68}$ The Flat Tax would be imposed on gross receipts from the sale of property or services in, or the export of property or

60. See id. (to be codified at I.R.C. $\S 20(a)(1)$ ).

61. See id. (to be codified at I.R.C. $\$ 17(\mathrm{~d})$ ).

62. All business income would be taxed under the above-described business tax. See discussion supra Part II.B.2.a.

63. See S. 722, 104th Cong. $\S 1$ (B) (1995) (to be codified at I.R.C. $\$ 131(a)(1)$ ).

64. See id. (to be codified at I.R.C. $\$ 202$ (b)(2)). The withholding rules currently found in Chapter 3 of the Internal Revenue Code would be redesignated unchanged as Chapter 5.

65. See I.R.C. \& 1441(c)(1) (1994).

66. See S. 722, 104th Cong. \& 1(B) (1995) (to be codified at I.R.C. \& 133(b)).

67. See id. (to be codified at I.R.C. \& 133(c)).

68. See Freedom and Fairness Restoration Act of 1995, H.R. 2060, 104th Cong. $§ 101$ (1995) (to be codified at I.R.C. $\S 11$ ). 
services from, the United States, minus the cost of business inputs, cash wages, and retirement contributions. ${ }^{69}$ Thus, the tax would be imposed on an origin basis, with exports taxed and imports excluded from the tax base. Dividends and interest would not be taxed, and payments for compensation would be deductible. This scheme implies that not all value added would be taxed at the business level; compensation would be taxed at the individual level.

Taxation of foreign business activity. The Flat Tax would not tax business activity outside the United States, even if conducted through a foreign branch or a subsidiary of a domestic corporation. ${ }^{70}$ Because the system is "territorial" in nature, no foreign tax credits would be allowed. As proposed, the Flat Tax contains no rules for allocating expenses between or attributing expenses to domestic or foreign income, for U.S. or foreign taxpayers. ${ }^{71}$ Likewise, there are no "anti-deferral" rules and no tax cost associated with repatriating earnings to the United States. Nor are there rules governing the taxation of pre-effective date earnings retained in foreign subsidiaries.

\section{b. Individual Tax}

Taxation of U.S. wage income. The Flat Tax would tax individuals at a flat $17 \%$ rate (after phase-in through 1997) on the amounts received as employee compensation for services in the United States, retirement distributions, and unemployment compensation, with a standard deduction ( $\$ 21,400$ for husband and wife and $\$ 5,000$ per dependent). ${ }^{72}$ There would be no deduction for home mortgage interest, charitable contributions, or state and local taxes. An individual would not be taxed on interest, dividends, rents royalties, or any other form of income from capital.

Income would include only compensation for services rendered in the United States; interest, dividends, and capital gains would be excluded. Under the Flat Tax uniform treatment would be accorded to all persons, citizens and aliens alike. Current special income tax provisions for both resident and nonresident aliens would thus be eliminated.

69. See id. (to be codified at I.R.C. §11(c)-(d)).

70. See id. (to be codified at I.R.C. $\$ 11(\mathrm{c})(2)$ ).

71. See id. (to be codified at I.R.C. \& 11).

72. See id. (to be codified at I.R.C. $\$ \S 1,63$ ). 


\section{Taxation of Cross-Border Activity: Origin- Versus Destination-Based TAXes ${ }^{73}$}

\section{A. Border Tax Adjustments}

As previously discussed, existing consumption taxes used by states and foreign countries are designed, in general, to apply to domestic consumption, and therefore are referred to as "destination-based." That is, tax is imposed at the rate applied by the country of consumption, which receives the revenue. The term "border adjustment" is generally used to refer to removal by the exporting country of a VAT imposed on exports, so that goods and services may move internationally free of such taxes. Parallel to this removal of taxes on exported goods and services, "border-adjustable" taxes may be imposed by the importing country. In other words, border adjustments are used to implement a destinationbased tax.

The origin and destination principles for the VAT produce different results where the tax in question is not uniform across all goods and services produced (or all factor incomes earned) in the economy. The destination principle minimizes price distortions facing producers, as producers still receive world prices, while the origin principle minimizes price distortions facing consumers, as prices will have been adjusted to match world prices including the tax. ${ }^{74}$ Production distortions may be worse in terms of welfare loss, which points toward favoring the destination basis. As Hufbauer and Gabyzon point out, firms in affected sectors are more likely to notice and complain about the distortions than are consumers of the affected products. ${ }^{75}$

\section{B. Effects on Trade}

Many proponents of U.S. tax reform have suggested that any new tax should be adjustable in order to increase U.S. competitiveness by eliminating the domestic tax burden from U.S. exports. ${ }^{76}$ Economic theory holds, however, that the origin and destination systems yield equivalent trade flow results as long as exchange rates between and/or domestic wages in the trading countries are flexible. ${ }^{77}$ Thus, whether a new consumption tax regime were deemed adjustable or not (or, more

73. Part III relies heavily on Victoria P. Summers, The Border Adjustability of Consumption Taxes, Existing and Proposed, 12 TAx NotEs INT'L 1793 (June 3, 1996); Baer et al., supra note 21.

74. See Hufbauer \& Gabyzon, Fundamental Tax Reform and Border Tax ADJUSTMENTS 23-24 (1996).

75. See id. at 24.

76. See, e.g., Summers, supra note 73, at 1799.

77. See id. 
broadly, were based on destination or origin), should not make any difference to the real U.S. balance of trade in the long run. ${ }^{78}$

Consider, for instance, adding a destination-based consumption tax to an existing economy. The economic effect would be a one-time price increase by the tax rate, but there would be no effect on trade flows. The tax would be removed with respect to exports, thus leaving unaffected the relative price of exports in the destination country. The tax would be added to imports at the border, making imports more expensive in absolute terms but leaving the price of domestic goods unchanged because the consumption tax is also imposed on domestic goods. While switching from a destination to an origin base would seem to disadvantage exports, this effect could not be maintained. ${ }^{79}$ If either relative wages or exchange rates between countries are flexible, one or both would adjust so that real trade flows remained constant, while relative prices changed. ${ }^{80}$ In the case of taxes which are not applied evenly to all activities use, of the origin principle actually may affect trade, however, as adjustment of price levels and exchange rates would be general and would relate to the overall burden of the tax, rather than specifically adjusting for each sector. Thus, a traded sector that was taxed more heavily than the economy as a whole, could, under an origin-based tax, be disadvantaged relative to competing production from other countries. ${ }^{81}$

On the other hand, it is quite possible that elimination of the income tax itself, as proposed in both the USA tax and the Flat Tax, could have effects on U.S. trade, regardless of the adjustability or nonadjustability of the replacement consumption tax. ${ }^{82}$ The direction of such effects is not entirely clear.

\section{International Practice}

All existing VATs are destination based ${ }^{83}$ For trade within the

78. See id.; see generally Hufbauer \& Gabyzon, supra note 74; Feldstein \& Krugman, supra note 21.

79. See Summers, supra note 73, at 1799.

80. See id., Baer et al., supra note 21; Lockwood et al., On the European Union VAT Proposals: The Superiority of Origin over Destination Taxation, 16 Fiscal STUd. 1 (1995). This result depends upon the taxes in question being general and comprehensive.

81. It should be noted, however, that even a border-adjusted (destination-based) tax which falls most heavily on one sector of the economy will disadvantage that sector relative to other sectors (leaving aside trade), and may cause it to contract. Thus, border adjustments are not necessarily the solution to all, or even the worst, ills of non-uniform taxes. See Feldstein \& KRUGMAN, supra note 21, at 270-72.

82. See Summers, supra note 73 , at 1799; see also Grubert \& Newlon, supra note 18 , at 624 43.

83. The only exception is for trade among the countries of the former Soviet Union. Trade 
European Union ("EU"), the destination principle applies, ${ }^{84}$ even after the elimination of border controls between the countries. The system is presently implemented under what is referred to as a "deferred payment" method. Exports to traders registered for VAT are zero-rated, as under the standard (with border) destination method. Documentary evidence of export, rather than actual border clearance, is necessary, however, in order for the export to be zero-rated. Imports from other EU countries are not charged VAT at the border. Instead, importers pay VAT on imports upon filing their normal VAT return. They then claim a credit for that VAT against the VAT charged on their sales, just as if they had paid VAT at the border as under the standard system.

There is discussion within the EU of moving to a "clearing house" mechanism, if the EU retains the destination basis. ${ }^{85}$ Under this system, the exporting country would levy its VAT on the export, as under the origin principle, and the importing country would allow a full credit for the VAT paid to the exporting country to the taxpayer using the import in production or for resale. Under current plans, however, the clearing house mechanism would reallocate revenues between the countries based on macro economic statistics, to provide a net economic result reasonably close to that which would be derived under the existing destination system. The net reallocation would flow from the net exporting countries to the net importing countries.

\section{Consistency with the GATT ${ }^{86}$}

While, theoretically, under its national law any country could adopt any tax treatment with respect to imports and exports, the legal issue of "adjustability" with respect to goods is governed by the terms of GATT $1994 .{ }^{87}$ Under GATT 1994, the issue with respect to exports is whether the remission of the taxes in question constitutes a prohibited export subsidy. ${ }^{88}$ Two criteria must be met if a tax remission is not to be

with third countries is on the destination basis. The current regime will likely be gradually replaced by a full destination system.

84. An exception applies with respect to cross-border shopping by final consumers.

85. See A Common System of VAT from the Commission of European Communitites, $\operatorname{COM}(96) 328$, Brussels, July 22,1996 . This mechanism is frequently referred to as an "origin system," because tax is levied in the country of production, but actually it is not an origin system in the economic sense.

86. This section relies heavily on Summers, supra note 73.

87. Under GATT 1994, the General Agreement on Trade in Services (GATS) has introduced a new regulation of trade in services. These rules are far less detailed and developed than rules respecting trade in goods, so the following discussion is limited to trade in goods.

88. Prior to GATT 1994, the term "subsidy" was not defined. GATT 1994 identifies three categories of non-agricultural subsidies (generally defined as direct or indirect financial contributions by a government conferring a benefit): non-actionable, prohibited, and actionable subsidies. Export subsidies are prohibited in all cases. When a prohibited subsidy is alleged, 
deemed a prohibited subsidy. First, the tax must be one of the "indirect" taxes set forth in the Agreement on Subsidies and Countervailing Measures. ${ }^{89}$ Second, the rebate on export must not exceed the amount levied on the goods sold for domestic consumption..$^{90}$

Imports must meet certain national treatment requirements.91 Further, while technically the direct/indirect dichotomy concerning export subsidies applies only to exports, some have concluded that the same test would logically apply with respect to whether the tax could be applied to imported products. ${ }^{92}$

Of course, whether or not something constitutes a "direct" or "indirect" tax for purposes of GATT is a legal question (apparently one of first impression with respect to the U.S. tax reform proposals), which ultimately must be answered within the terms of the applicable trade law. As analyzed more fully below, arguments may be made on both

consultations may be undertaken, followed by initiation of dispute resolution procedures. If such a subsidy is found to exist, it must be revoked, regardless of whether it has adverse effects. Actionable subsidies are permitted, but if adverse effects are found under the dispute resolution procedure, the subsidy must either be revoked or the affected country compensated. Alternatively, countervailing duty investigations may be undertaken, resulting in unilateral action by a WTO member. See Summers, supra, note 73, at 1795 n.7.

89. "Indirect taxes" include sales, excise, turnover, value added, franchise, stamp, transfer, inventory and equipment, border, taxes and all taxes other than direct taxes and import charges. Direct taxes are defined as taxes on all forms of income, including wages, profits, interests, rents, and royalties, and taxes on the ownership of real property. See id. at $1795 \mathrm{n.8}$.

90. One example of a prohibited export subsidy is "exemption or remission in respect of the production and distribution of exported products of indirect taxes in excess of those levied in respect of the production and distribution of like products when sold for domestic consumption." Id. at 1795 n.9.

91. Products imported from the territory of one contracting party to another are not subject to direct or indirect internal taxes or charges of any kind exceeding those applied, directly or indirectly, to like domestic products.

92. As Hufbauer and Gabyzon point out, however, the actual wording of GATT is not symmetric as between imports and exports:

The language of Article III:2 permits the imposition of 'internal taxes or other internal charges' equal to those imposed directly or indirectly on like domestic products. This language would seemingly open the door (for example) to the imposition of an energy tax on imported goods to complement a tax on energy used in making like domestic goods. It might also seem to open the door for the imposition of corporate taxes equivalent to thcse paid by domestic manufacturers of like products. However, neither the energy tax nor the corporate income tax could be rebated on exports under the Tokyo Round agreement for the reason ... that the phrase 'borne by the like product' contained in the note to Article XIV was interpreted in the Tokyo Round Subsidies Code to exclude the rebate both of taxes occultes (e.g., an energy tax) and direct taxes .... . Symmetry in applying the destination principle correspondingly argues for not imposing such taxes on imports.

HufBaUER \& GaBYZON, supra note 74 at 53-54. See also Letter from the Assistant Secretary for Tax Policy, U.S. Department of the Treasury, to Sam Nunn, Senator, U.S. Congress (Feb. 1995) [hereinafter Treasury Letter]. 
sides. In contrast, whether or not the "rebate" (exemption) on exports would exceed the tax imposed if the product were sold domestically, and, conversely, whether or not the tax imposed at import would exceed that imposed on the same product produced domestically, appear to be questions of fact.

\section{DIRECT VERSUS INDIRECT TAXES}

The list of "indirect" taxes in GATT 1994 includes "value-added" taxes. It is generally accepted that this definition includes the creditinvoice method of taxing added value, as the European VAT was the only type actually in use when the list was written. Indeed, the real question is whether any type of consumption tax other than the creditinvoice model would be included in this definition.

The credit-invoice tax is transactions based. On every sale by a taxpayer, the tax is imposed by applying the relevant tax rate to the commodity's price. The taxpayer's total tax liability for each tax period is the total of all these taxes on all of its taxable sales, less the taxes paid on all purchases of taxable business inputs, as evidenced by invoices from its suppliers. Exported products are "zero-rated," that is, they are treated as taxable, but at a rate of zero. Thus, no tax liability arises on export sales. Taxes paid to suppliers on inputs to produce the exported products are creditable, however, just as if the sales were domestic. ${ }^{93}$

The business portion of the USA tax is a subtractive-method VAT. As an economic matter, a subtractive VAT like the USA tax and a credit-invoice VAT are both levied on the same tax base, that is, wages plus profits (before debt service), defined as the value added by each taxpayer at each stage of production. And, as noted above, "direct" taxes are defined as those on "forms of income" and real property. The corporate income tax base, as generally defined, excludes wages and thus does not correspond to the VAT tax base. The nature of the tax base is not necessarily the relevant test under GATT, however.

The GATT Working Party on Border Tax Adjustment concluded in its 1970 Report in the context of remissions on export that there was a consensus that indirect taxes were those levied directly on products. It was further agreed that the "fractioned collection" tax on value added (i.e., the credit-invoice tax) was equivalent to a retail or sales tax levied directly on products, despite the fractioned collection process. ${ }^{94}$

93. A taxpayer selling only for export would have net negative tax liability in every period, and would receive refunds of all taxes paid with respect to inputs. This does not constitute a prohibited subsidy, it simply removes all domestic VAT included in the product price prior to export. See Summers, supra note 73, at 1796 n.14.

94. Hufbauer and Gabyzon conclude that GATT would permit adjustment on both imports 


\section{IMPOSSIBILITY OF EXCESS REBATES OF TAX}

The structure of the credit-invoice VAT assures that amounts in excess of taxes paid on exports are not rebated, and that taxes on imports do not exceed taxes imposed on like domestic products. Because taxes paid during the period are offset against the tax liability incurred, no excess rebates occur with respect to these exports. Only taxes actually paid with respect to purchases of inputs may be rebated. This is true under the credit-invoice method even when inputs into exported products are exempt from VAT or taxed at a different rate.

There is a crucial difference between a credit-invoice VAT and a "subtractive-method" tax such as that included in the USA tax proposal. With a subtractive VAT, if no adjustments were made for inputs exempted or taxed at a lower rate, allowing a deduction for inputs to an exempted export would permit a "rebate" of more tax than was imposed with respect to the export. Adjustments could be made for inputs exempted or taxed at different rates, but this would be extremely burdensome as each item of tax paid would have to be tracked.

\section{ANALYSIS OF GATT APPLICATION TO THE TAX REFORM PROPOSALS}

Retail sales tax. The retail sales tax would be imposed, by definition, on a destination basis, if it applied only to retail sales within the United States. ${ }^{95}$ It would not be necessary to impose a tax at the border on imported consumer goods to be sold through U.S. retailers. A retail sales tax would have to be imposed on direct imports by consumers, however, or the tax base would be eroded by mail order sales from abroad, by goods brought in from abroad through airports, and, presumably, by cross-border shopping along the Canadian and Mexican borders. ${ }^{96}$ The retail sales tax accounts for this possibility, but the likelihood of meaningful enforcement is extremely low. Experience at the state level suggests that communities bordering Canada and Mexico would find substantial cross-border shopping. None of this raises GATT issues, however.

USA tax. Proponents of the USA tax assert that the business portion would be border adjustable under GATT 1994. The proposed legislation provides that exports would not be subject to the tax, that inputs

and exports of services with respect to direct, as well as indirect, taxes. See HuFBauER \& GABYZON, supra note 74.

95. See Summers, supra note 73 , at 1798. As drafted, the retail sales tax would provide an option for businesses to charge tax on all sales, to avoid the necessity of determining which should be exempt, and would allow the purchaser to take a corresponding credit. Of course, this would make the tax similar to a credit-method VAT.

96. See id. 
used to produce exports could be deducted from taxable sales, ${ }^{97}$ and that the tax would be imposed on imports. Therefore, it would be a destination-based tax. There are three main issues with respect to the adjustability of this tax.

The first issue is whether, given the subtractive nature of the tax, it could be viewed as "indirect" under GATT. Under existing precedents and reports, it would seem that the tax would be levied directly on products, as discussed above. It could be argued that this tax would not be so imposed, as it is not "transactions-based" like the credit-invoice tax. On the other hand, it could also be argued that the traditional terminology distinction between "transactions-based" and "accounts-based" taxes is fallacious here. In fact, in the credit-invoice VAT, aggregate input tax paid is subtracted from aggregate tax liability incurred on all sales for every taxable period. Inputs and outputs are not matched for each individual item sold..$^{98}$ Tax calculations, by both taxpayers and tax collectors, are done from accounts for each period.

By this standard, the only difference between the credit-invoice tax and the subtractive tax is that tax paid is subtracted from tax liability in the former, while in the latter, input costs are subtracted from total sales and the result multiplied by the applicable tax rate. Thus, it could be argued that the equivalence of the tax base should make this tax, like the credit-invoice tax, equivalent to a retail sales tax for GATT purposes. The base being taxed is not "income," as defined by the definition of direct taxes in GATT. However, this question has not been directly addressed or answered by GATT panels or working groups.

The second issue is the potential excess rebating of input costs when deductible payments are made for goods or services exempt from VAT or subject to a lower rate than the product being exported. Under the subtractive tax, as generally structured, all input costs are deducted from taxable sales to derive net tax liability. If no tax were paid with respect to some of these costs, they would still be deducted, absent some special method for changing this result. Thus, if all sales were zero-

97. This effectively constitutes zero-rating in a subtractive method VAT. To see this, it is helpful to consider the extreme case in which all sales by a taxpayer are exports and are therefore untaxed. If all business purchases are deducted from (zero) taxable sales, the result will be a negative number in every period. When this net (negative) liability is multiplied by the tax rate, a credit will be generated equal to the amount of tax paid on the purchased business inputs. If this credit is refunded to the exporter, all tax otherwise included in the exported products will have been returned, and the goods will leave the country free of tax. It should be noted, however, that the USA tax does not permit such refunds, but instead requires a carry-forward of excess deductions. See id. at 1797 n.17.

98. Individual physical tracking of items with specific matching of individual items was incorporated into the original Soviet and post-Soviet VATs of the former Soviet Union countries, and was viewed as one of their major structural flaws. See id. at 1797 n.18. 
rated, and if some inputs were exempt from VAT on purchase, but all input costs were deducted for the tax period, a refund would be generated in the amount of tax that would have been paid on the inputs if they were all taxable. However, since the full tax would not have been paid, an "excess" refund would result, which, under GATT 1994, could be deemed to subsidize the zero-rated exported product. ${ }^{99}$

This divergence from the credit-invoice tax comes from the fact that tax actually paid is not tracked in the standard subtractive, accountsbased method. Rather, the total sales and total purchases are taken from the accounts for each tax period. It would, of course, be theoretically possible to keep track of which inputs were subject to tax and which were not, as is done in Japan, ${ }^{100}$ and subtract only the costs of those that were taxed. ${ }^{101}$ This would be more complicated. Further, it would be even harder to utilize a system in which inputs were deducted from sales if some inputs were not exempt but were taxed at different rates. In other words, if inputs were treated differently from one another, it would be impossible to ensure that there would be no over-refunding without tracking actual tax paid, as opposed to total input purchases and sales. ${ }^{102}$ As long as there were no intermediate exemptions or preferential rates with respect to any inputs into exported goods and services, theoretically no prohibited export subsidy would result, assuming the tax were deemed to constitute an "indirect" tax under GATT, as discussed above.

Finally, the USA tax as proposed would include a credit for payroll taxes. This could be interpreted as a prohibited exemption of direct (i.e.,

99. For example: Assume that total sales for a period are 200, the standard tax rate is 20 percent, 50 of inputs into the products sold are taxable at the standard rate of 20 percent, and 100 of inputs are exempt from tax. Value-added at the final stage is $\mathbf{5 0}$, and the goods are exported so are zero-rated. The comparative results would be as follows:

(1) Tax on sales

(2) Sales subject to tax

(3) Credits for input tax

(4) Input costs subtracted

(5) Net due

$$
\begin{gathered}
\text { A } \\
\text { Credit--invoice } \\
200 \times 0 \%=0 \\
-\overline{50}=10 \\
100 \times 0 \%=0 \\
0-10=-10 \\
\text { (line (1) - line (3)) }
\end{gathered}
$$

B

$$
\begin{gathered}
\text { Subtractive } \\
\overline{0} \\
- \\
150 \\
0-150=-150 \\
(\text { line }(2)-\operatorname{line}(4)) \\
-150 \times 20 \%=-30
\end{gathered}
$$

In effect, the unpaid tax on the exempt 100 input is refunded. Obviously, this could be corrected if a separate account were kept of the untaxed inputs.

100. The Japanese tax is "accounts-based." It derives net tax liability by calculating tax on sales and subtracting the tax rate times the business inputs. In most instances, only taxable inputs are included in the tax offset calculation. However, sales by small to medium-sized businesses are exempt, but purchases are treated as taxable for purposes of calculating the purchasing business' tax credit. Thus, the tax would be subject to challenge under GATT.

101. See id. at 1798.

102. See id. 
payroll) taxes with respect to exports, even if the tax otherwise passed muster as an indirect tax for GATT purposes. With respect to imports, it has been suggested that allowing a payroll tax credit for work performed in the United States against the USA tax imposed on such domestically produced goods, while not allowing an equivalent credit with respect to imported goods might violate national treatment requirements. ${ }^{103}$

The Flat Tax. Like the USA tax, the business and individual portions of the Flat Tax, taken together, are intended to be consumptionbased. ${ }^{104}$ However, the mechanical division of the tax base between the two is quite different. The USA tax is really a business-level, subtractive-method, indirect tax on value added, coupled with a personal direct consumption tax at the individual level. The Flat Tax, on the other hand, is not a tax on value added at the business level, because wages are deductible from the base at that level. Thus, under existing GATT rules, the business tax would clearly be deemed a form of direct, i.e., income, rather than indirect, tax.

Recognizing this, sponsors and proponents of the Flat Tax do not intend its business portion to be border adjustable. It is an origin-based tax. Under the tax, U.S. production would be taxed regardless of whether it were exported or consumed here, and imports would not be taxed. ${ }^{105}$

\section{E. Conclusions}

In the case of taxes which are not applied evenly to all activities, use of the origin principle actually may affect trade, as adjustment of price levels and exchange rates would be general and would relate to the overall burden of the tax, rather than specifically adjusting for each sector. Thus, a traded sector that was taxed more heavily than the economy as a whole, could under an origin-based tax be disadvantaged relative to competing production from other countries. The increased possibility of production distortions under a non-uniform origin-based tax may lead to an economic preference for a destination-based tax. Further, some effects on trade could be felt in the short-run even if a uniform origin-

103. See Treasury Letter, supra note 92 . In making this argument, it is necessary to contrast the credit of the payroll tax with the effective crediting of the USA tax paid at earlier stages of production, which, of course, applies to domestic production but not to imports (because the tax on imports was not collected prior to importation into the United States). The latter is clearly acceptable: it constitutes a refund of the tax itself and is necessary to appropriately measure the tax base. The former-that is, the offset of a direct tax-has not been tested under GATT. See Summers, supra note 73 , at 1798 n.20.

104. See id. at 1798. A substantial threshold exemption is provided for wages paid to individual taxpayers, however. See id. at 1798 n.21.

105. See id. at 1798. 
based tax were introduced, and if exchange rates or wages did not adjust, real trade differences between origin and destination-based taxes could result.

Additional administrative considerations favoring a destinationbased tax include the practical difficulties of ensuring that imports are not taxed under an origin-based system, and the enforcement difficulties of ensuring that prices received for exports, which are taxed under an origin system, are the actual prices paid.

Despite the long-term theoretical economic equivalence of uniform origin and destination-based taxes with respect to trade flows (assuming adjustment of wages or exchange rates), adjustability versus nonadjustability has been both a source of contention between trading partners and of political palatability with respect to the introduction of certain taxes. ${ }^{106}$ Irrespective of economic theory, the widespread misconception that the destination-based VAT constitutes some sort of export subsidy and import protection has often been more persuasive to policy makers than have arguments concerning the long-run economic effects. ${ }^{107}$

To the extent that border adjustability consistent with the GATT is desirable, the most straightforward approach would be to adopt either a retail sales tax or to follow the general international practice of using a credit-invoice method VAT. If the USA business tax subtractivemethod VAT were adopted, it would be important to employ a uniform rate for all business taxpayers. Even then, as discussed above, there would be some question whether it was indeed an "indirect tax" for GATT purposes. Finally, under existing international law, the deduction of wages at the business level-used in the Flat Tax in order to allow progressivity at the lowest end of the income spectrum by exempting earned income from the overall tax-would preclude the use of border adjustments, and hence require an origin-based tax. If this approach were adopted, keeping the tax fully uniform would also be of utmost importance in order to minimize price distortions.

106. See Summers, supra note 73 , at $1799-1800$. This was certainly the case with respect to the U.S. reaction when European nations introduced general VATs.

107. See id.; see also FeldsteIn \& KRUGMAN, supra note 21, at 263. 
F. Overview of Tax Reform Proposals and GATT Consistency

The following table summarizes the discussion thus far:

Overview of Tax Reform Proposals

\begin{tabular}{|c|c|c|c|c|c|}
\hline & $\begin{array}{l}\text { Method of } \\
\text { Tax }\end{array}$ & $\begin{array}{l}\text { How } \\
\text { Collected }\end{array}$ & $\begin{array}{l}\text { Transaction } \\
\text { or Accounts } \\
\text { Based }\end{array}$ & $\begin{array}{l}\text { Origin or } \\
\text { Destination }\end{array}$ & $\begin{array}{l}\text { Consistent } \\
\text { with GATT }\end{array}$ \\
\hline $\begin{array}{l}\text { Retail Sales } \\
\text { Tax }\end{array}$ & $\begin{array}{l}\text { Tax on retail } \\
\text { sale }\end{array}$ & $\begin{array}{l}\text { By business } \\
\text { seller (non- } \\
\text { business of } \\
\text { imports) }\end{array}$ & Transactions & Destination & Yes \\
\hline \multicolumn{6}{|l|}{ USA Tax } \\
\hline Business & $\begin{array}{l}\text { Subtraction } \\
\text { method VAT }\end{array}$ & $\begin{array}{l}\text { Business tax } \\
\text { return }\end{array}$ & Accounts & Destination & $\begin{array}{l}\text { May be, but } \\
\text { note credit } \\
\text { for payroll } \\
\text { tax }\end{array}$ \\
\hline Individual & $\begin{array}{l}\text { Tax on } \\
\text { consumed } \\
\text { income-cash } \\
\text { flow method } \\
\end{array}$ & $\begin{array}{l}\text { Individual } \\
\text { tax return }\end{array}$ & Accounts & N/A & N/A \\
\hline \multicolumn{6}{|l|}{ Flat Tax } \\
\hline Business & $\begin{array}{l}\text { Variation of } \\
\text { subtraction } \\
\text { method } \\
\text { VAT, note } \\
\text { deduction for } \\
\text { compensation }\end{array}$ & $\begin{array}{l}\text { Business tax } \\
\text { return }\end{array}$ & Accounts & Origin & $\mathrm{N} / \mathrm{A}$ \\
\hline Individual & $\begin{array}{l}\text { Tax on } \\
\text { consumed } \\
\text { income-yield } \\
\text { exemption } \\
\text { method }\end{array}$ & $\begin{array}{l}\text { Individual } \\
\text { tax return }\end{array}$ & Accounts & N/A & N/A \\
\hline
\end{tabular}

IV. Treatment of Cross-Border Services in General and Financial Services in Particular

\section{A. Cross-Border Services in General}

Just as under an income tax, the taxation of cross-border services under a consumption tax presents vexatious issues, both theoretical and administrative. In order to determine whether any particular service is taxable in a specific country, it is necessary to define the place at which the service is deemed supplied. Determining the place where services are sold or provided is not always straightforward. It is clear that a haircut performed in New York is a service provided in the United States. However, the "location" of legal services provided is far less clear when conducted via telephone by an American partner of a U.S. law firm, while in Paris, either at a hotel or the firm's affiliated Paris office, to a Russian business in Moscow. 
For this and related administrative reasons, most state retail sales taxes in the United States typically exclude services altogether. ${ }^{108}$ Most VAT laws, however, include rules defining where services originate. Some "cross-border" services are deemed to take place inside the country at issue, and are therefore taxed there, while other services having some connection to the country's taxpayers or consumers are nonetheless deemed to take place outside the country, and thus are not taxed in that country. In the European-model VAT, services are not normally treated as "imported" or "exported."

Rules under existing VAT laws. The general rule of the European VAT laws, as reflected in the Sixth Directive, is that services are deemed supplied at the location of the supplier's business from which the services are supplied. ${ }^{109}$ However, there are exceptions to this rule for cultural, artistic, sporting, and educational activities, and work on movable tangible property, which are deemed provided where the service is physically carried out; ${ }^{110}$ services connected with immovable property, which are deemed provided at the location of the property; ${ }^{111}$ transportation services; 112 and certain so-called "intangible" services. The "intangible" services are subjected to the so-called "reverse-charging rules", ${ }^{113}$ inclusive of the following types of services: (i) transfers or assignments of patents, copyrights, licenses, trademarks, or similar rights; (ii) services of consultants, engineers, lawyers, architects, and accountants, and data processing or similar services; (iii) advertising services; (iv) the obligation to refrain from pursuing or exercising a business activity; (v) the supply of personnel; and (vi) the services of an agent in procuring any of the foregoing services. ${ }^{14}$

The reverse-charging rules work by imposing the obligation to pay VAT on the recipient of the service in his or her own country, rather than on the supplier in its country. ${ }^{115}$ The customer in effect is charged VAT on top of the price of the service, and remits this as a regular VAT liability. If he has acquired the service for use in the production of a taxable transaction, the customer/VAT payor would receive a credit for the VAT so paid and there would be no net effect. ${ }^{116}$ The object of this

108. Many will recall the questions which arose during Florida's brief foray into taxing services, including legal services, in the 1980s.

109. See Council Directive 77/338, art. 9(1), 1977 O.J. (L 145) 77 (as amended by Council Directives 91/680, 92/111, 94/5) [hereinafter the Sixth Directive].

110. See id. art. $9(2)(\mathrm{c})$.

111. See id. art. 9(2)(a).

112. See id. art. $9(2)(\mathrm{b})$. See infra Part IV.C for discussion of transportation services.

113. See id. art. $9(2)(\mathrm{e})$.

114. See id. art. 21(1)(b).

115. See id.

116. See id. art. 17(2). 
arrangement is to avoid distortions of trade in the case of exempt and partially exempt purchasers. ${ }^{117}$ If there were no reverse charging provision, such taxpayers (because they are not entitled to a credit for VAT paid on inputs) would have an incentive to order services from abroad, free from domestic tax, rather than purchasing them domestically where they would be subject to VAT. This is a major issue with respect to financial services suppliers, who generally are exempt. Reverse charging rules apply to those services that are easily provided from any location, and the provision of which could be moved in order to achieve the most favorable tax results.

In Europe, the provision of services to which a reverse charge would apply (if received in the country from elsewhere) by businesses within the country to outside persons are typically zero-rated. Services to which a reverse charge rule applies are similar in this respect to traded goods. The "importer" is taxable with respect to them, ${ }^{118}$ and, if they are used in the production of a taxable transaction, a credit is taken for the tax paid on the import. ${ }^{19}$ Such services which are "exported" are also zero-rated. Thus, VAT on inputs into services provided to recipients abroad and which are of the type subject to the reverse charging rule (that is, deemed to be provided abroad) would be subject to credit.

It should be noted that in the European tax system, this analogy to goods directly applies only to the reverse charged services. Other services which are deemed provided within the taxing country because performed at a taxpayer's business location there, even if sold for use by a person outside the country, would not be treated as exported. ${ }^{120}$ They would be subject to the domestic VAT liability, and credit on inputs, in the usual way. Similarly, services which are deemed provided outside the taxing country because from a location elsewhere, or, for example, in connection with real estate in another country, would be deemed supplied where performed. Since, in that case, there is no supply within the taxing country, the transaction is not subject to the domestic VAT; nor, therefore, would inputs utilized in providing the service be creditable, as they would if the service were "zero-rated."

\section{THE RETAIL SALES TAX}

The place-of-supply rule for international services in the proposed retail sales tax apparently follows the rule for the more limited "reverse

117. Individual consumers who are unregistered persons and who acquire such "reversecharged" services from abroad will, as a practical matter, be unlikely to report and pay the VAT in most cases, even if legally required to do so.

118. See id. art. 21(2).

119. See id. art. 17(2)(b).

120. See id. 
charge" services in the European VATs. That is, services for use or consumption in the United States would be subject to the tax, regardless of where they were rendered, and the purchaser would be liable for the tax payment where the seller was outside the United States. ${ }^{121}$

Since this tax would be by definition applicable only to final sales to consumers, ${ }^{122}$ such a rule would be necessary to prevent choice distortion in purchasing services. Otherwise, the incentive would be to purchase from abroad rather than domestically. However, in the case of tangible services, such choices will not always, or even usually, be available. In the case of final consumers, such a rule will be almost impossible to enforce with respect to services, since services cannot easily be taxed as they cross the border.

\section{THE USA TAX}

The USA tax would treat both services and goods as exported and imported. ${ }^{123}$ Services would be deemed supplied where performed. ${ }^{124}$ Again, in some instances, determining where "performance" occurs is not always straightforward, and the bill provides special rules in connection with some of the most difficult cases, such as transportation, financial, and communications services. ${ }^{125}$ An "export" of a service would occur when the benefit of the service performed in the United States was realized solely outside the United States. ${ }^{126}$ Such services would be zero-rated. Services would be considered "imported" if the benefit of a service performed outside the United States and thus otherwise outside the tax net, were realized in the United States solely in connection with U.S. business activities. ${ }^{127}$ In this case, the recipient of the imported service would be responsible for paying the VAT with respect to those services. This is similar to the European reverse charging rule, but would apply to all services performed outside the United States, not just "intangible" services.

121. See H.R. 3039, 104th Cong. (1996) (to be codified at I.R.C. § 1(a)). A de minimis rule would apply to payments for imported services (and property) not exceeding $\$ 400$ per entry and $\$ 2,000$ per year. See id. (to be codified at I.R.C. \$ 2(b)).

122. Although in order to avoid a need for businesses to verify that their customers were indeed purchasing for resale or use in production, so that the sale would be exempt, the bill provides that sellers could charge the tax on all sales and allow the buyer to claim a credit for the tax paid. See id. (to be codified at I.R.C. § 3(b)). At this point, the tax looks suspiciously like a credit-method VAT.

123. See S. 722, 104th Cong. (1995) (to be codified at I.R.C. $\$ \S 267,286,287$ ).

124. See id. (to be codified at I.R.C. $\$ 267$ (a)).

125. See id. (to be codified at I.R.C. \$\$ 268, 269, 271).

126. See id. (to be codified at I.R.C. $\$ 267(\mathrm{c})$ ).

127. See id. (to be codified at I.R.C. \& 267(b)). 


\section{THE FLAT TAX}

Since the Flat Tax is origin-based, it intends to tax all services provided in the United States or exported. Imports, which apparently include services purchased abroad, would not be subject to the tax. Business activity of U.S. persons conducted abroad would not be taxable in general; thus, the location of intangible services such as consulting services would seem to be easily removed from the tax net by shifting them abroad. Since, under most existing VATs, such services provided abroad would be deemed taxable at the point of use, for consumption tax purposes, services performed for U.S. taxpayers from such locations would not be taxable.

\section{B. Financial Services}

Background. The financial services industries, encompassing, inter alia, banks and property, casualty and life insurance companies, present a challenge for income or consumption tax systems whenever services are compensated by a reduction in the customer's return on a financial asset. ${ }^{128}$ The bundling of services and investments makes it difficult to identify the value of services consumed and to measure the actual investment income.

The problem is illustrated by the example of a demand deposit that generates a below-market interest rate to the depositor in exchange for free checking services. Under the current income tax system, the depositor is not taxed on the income measured by difference between the amount paid on the deposit and a market return; yet the bank receives a deduction for the cost of providing the services. Professor Bradford observes that the income mismeasurement is only significant with respect to nonbusiness customers who would not be able to deduct any services explicitly charged. ${ }^{129}$ The same issue arises under a consumption tax in that it is necessary to determine the value added by a financial institution as distinct from the financial return on invested capital.

The difficulty in taxing financial institutions on a consumption basis is evidenced by the fact that almost every country that has adopted a generally applicable VAT has removed financial institutions from the VAT system. ${ }^{130}$ Nonetheless, each of the U.S. tax reform proposals

128. See generally DAVID F. BRADFORD, Treatment of Financial Services under Income and Consumption Taxes, in Economic EFfects of Fundamental TaX Reform 437 (Henry J. Aaron and William G. Gale eds., 1996).

129. See id. at 444 . Bradford also considers whether a non-business taxpayer should be entitled to a deduction for costs of checking.

130. See Sullivan, supra note 13, at 193-94, summarizing the distortions that can result from excluding financial institutions, depending upon how the exclusion is accomplished. 
would tax financial services.

Assuming that a financial service is identified and that its value could be determined (which are issues outside the scope of this paper), the international issue becomes one of identifying which services should be taxed. This requires a determination of where a service is used or consumed. Using a bank deposit as an example, should the location of the consumer of the service guide the inquiry? Practical administration suggests reference to a consumer's residence as a surrogate for determining where the service is consumed. This approach has a drawback, however, in that a resident of one country may have substantial activity outside the country of residence. For example, a Mexican resident may maintain an account in the United States primarily for issuing checks while present in, or to persons in, the United States.

An alternative approach would be to treat the service as consumed according to the location where the service is performed. The place-ofperformance approach has an administrative advantage in that the financial institution possesses information relating to where the service is performed. The location or residence of a customer at any given time might not be known to the financial institution. In the case of financial services, however, the determination of the place where services are performed is not always clear because the implicit service fees may not always be determined on a transaction-by-transaction basis.

Under the destination principle, one would expect that services "exported" for use or consumption outside the United States would not be taxed. Thus, whatever fees are determined to be for financial services consumed or performed abroad should be exempt (or zero-rated in a credit-invoice VAT). Under a VAT, the bank would obtain a refund of VAT on inputs with respect to the service under the credit-invoice method, or a deduction for associated expenses and a negative tax liability under the subtractive method. The service would be exempt under a retail sales tax.

If place of performance is used to determine where financial services are consumed and the destination principle is employed, a foreign bank with a U.S. branch that could not determine fees on a transaction basis would have to allocate a portion of implicit fees determined on a bank-wide basis to the U.S. branch and pay tax thereon. It would also be necessary to determine the bank's home office expenses to be allowed as deductions for the branch. Under the destination principle, other difficult issues would include whether services performed outside the United States for a U.S. resident while outside the United States should be exempt, and whether services performed in the United States for a nonresident present in the United States should be taxed. In the 
former case, exemption would be appropriate if it could be shown that the U.S. resident was outside the United States when the service was consumed. In the latter situation, exempting services to nonresidents present in the United States could be politically unpopular. For this reason, providing a "benefit" rule as described above with respect to the USA tax would be an appropriate modification to a general place-ofperformance rule. Thus, if cross-border services were provided for the benefit of a customer in another country, the service should be treated as supplied in the other country.

A good example of the complexities involved in taxing financial services would be a U.S. pension fund which places its worldwide equity portfolio with a global custodian and obtains a reduced custody fee in exchange for permitting the custodian to lend the equity securities in a securities lending program (which generates fees and returns on collateral balances for the bank). The fee paid to the bank is reduced as a result of the below-market return it pays the pension fund from investment of the collateral.

In this example, the bank is bundling two separate services, custody and securities lending, and using the financial return on securities-lending collateral to offset fees for both. Should the explicit and implicit fees charged by the bank be allocated between U.S. and non-U.S. lending on the basis of the costs of providing the service? Should it make a difference whether foreign securities generate higher lending fees so that the net custody fee is the same for U.S. and non-U.S. securities? Theoretically, the returns earned on securities lending collateral should make no difference. Arguably, any reasonable allocation which is consistently applied should be acceptable.

Notwithstanding these difficulties, each of the tax reform proposals attempts to tax financial intermediation services.

\section{THE RETAIL SALES TAX}

The retail sales tax would tax both explicitly and implicitly charged financial intermediation services. ${ }^{131}$ Implicitly charged financial services would be based on imputing a return of two percent over similar term government securities on any underlying interest-bearing investment, account or debt, and subtracting any explicitly charged fee for the service.

The general rule regarding the international aspects of the rules governing financial services is that tax is imposed on "gross payments

131. See H.R. 3039, 104th Cong. (1996) (to be codified at I.R.C. \& 21(a)(1)). The term "financial intermediation services" is defined as the sum of explicitly and implicitly charged services. See id. 
for the use, consumption or enjoyment in the United States of any taxable . . . service, whether . . . rendered within or without the United States." 132 A special rule relating to the place of consumption of "international financial intermediation services" provides:

Financial intermediation services shall be deemed as used, consumed or enjoyed within the United States if the financial intermediation services provider or any related party has a permanent establishment in the United States and the person purchasing the services is a resident of the United States. For purposes of the preceding sentence, the term 'related party' means, with respect to any financial institution, any corporation which is a member of a controlled group (as defined in former section 267(f)) which includes such institution. ${ }^{133}$

While the drafting leaves much to be desired, it appears that the general rule assumes that financial intermediation services provided to U.S. residents by U.S. service providers will be used in the United States and therefore taxable. It appears that the tax would not apply to U.S. customers "consuming" services outside the United States.

The "special rule" is apparently designed to ensure that a foreign financial institution with a U.S. presence (direct or through an affiliate) would be subject to U.S. taxation for services provided to U.S. residents from abroad. The rule would appear to make taxable the maintenance by a U.S. individual of a deposit account at a financial institution that has any branch or affiliate in the United States outside the United States. ${ }^{134}$ This may be objectionable to foreign financial institutions and would be very difficult to enforce without the cooperation of the foreign country.

\section{THE USA TAX}

The USA tax, unlike the retail sales tax, would not tax individuals on imputed consumption of financial services. This presumably is justified by a desire to encourage savings through financial institutions. Explicitly charged services would be taxable.

Under the USA business tax, a financial intermediation services provider would determine the gross profit attributable to financial intermediation activity on a worldwide basis and then reduce the total by that portion attributable to financial intermediation activity provided outside

132. Id. (to be codified at I.R.C. $\$ 1(a)$ ).

133. Id. (to be codified at I.R.C. $\$ 22(\mathrm{c})$ ). The term "financial institution" is not separately defined. Although the brevity of H.R. 3039 is assisted by omitting definitions and by crossreferencing repealed sections of the Internal Revenue Code of 1986, we would encourage drafters to incorporate such definitions in the text of tax reform legislation.

134. This presumably would prompt the publication of a directory of financial institutions without such affiliations. 
the United States. ${ }^{135}$ The unofficial description of the proposal indicates that services would be considered provided at the location of the bank offices and where the banks' employees and independent contractors provide services to the bank. The USA business tax proposes a costbased formula apportionment method to determine non-U.S. services where $65 \%$ is based on the ratio of foreign wages and salaries to total wages and salaries for all services, and $35 \%$ is based on the ratio of foreign deductible expenses to all deductible expenses. Separate rules are prescribed for insurance companies. ${ }^{136}$

The USA tax approach to determining the non-U.S. portion of financial intermediation services seems arbitrary but not unreasonable. It is not clear why the proponents suggest a $65 / 35$ weighting for the payroll and other deductible payment elements of the apportionment fraction. It may be desirable to allow some flexibility in the allocation formula, so long as it is consistently applied, in order to accommodate different types of financial services.

\section{THE FLAT TAX}

The Flat Tax on business activities would apply to taxable income from financial intermediation services. Taxable income from such services "shall be equal to the value of the intermediation services provided in such activity." 137 No further description is provided concerning how this value is to be determined. The Flat Tax would tax services in the United States or exported from the United States. It is not clear what is intended to be covered by the concept of exported services, but it appears to refer to services performed in the United States and consumed abroad. ${ }^{138}$ Accordingly, all U.S.-performed financial intermediation services would be taxed. The failure to tax imported financial services would seem to leave an invitation to provide financial services from offshore financial centers.

\section{SUMMARY}

The most difficult issues relating to the taxation of financial services involve measurement and whether it is worth the complexity and administrative and enforcement burdens that would be necessary to tax these services. Cross-border issues are an important, but secondary concern.

From an administrability perspective, if the destination principle

135. See S. 722, 104th Cong. (1995) (to be codified at I.R.C. \& 242(c)).

136. See id. (to be codified at I.R.C. $\$ 244$ ).

137. H.R. 2060, 104th Cong., § 11(e) (1995).

138. See id. \& 11(c). 
were adopted as the general rule, place of-performance modified by a residence-of-customer rule for services provided from outside the destination country would seem a sensible determinant of intermediation services to be taxed. Thus, all services performed in the United States would be taxable unless performed exclusively for a nonresident customer, in which case the services would be exempted as an export. Imported financial services would be taxed when performed for a business purchaser. If an attempt were made to tax financial services, the USA tax rules would serve as a reasonable starting point.

\section{Summary}

This part suggests that just as under the income tax, it is even more difficult to apply a consumption tax to the taxation of cross-border services than to sales of goods. It may be difficult to identify the customer. In addition, the location of cross-border services is ambiguous. As a result, the existing tax reform proposals appear to employ both a placeof-performance and a benefit test to determine the location of services.

The challenge which cross-border services present to an indirect tax on consumption likely will be intensified by the proliferation of services provided through the Internet and other electronic means, possibly from locations other than countries with well-developed tax systems. The relative difficulty in applying consumption taxes to cross-border services may have implications for economies in which such services are and will continue to be increasingly important. To the extent that the current tax reform proposals rely on non-business consumers to implement a reverse-charge mechanism, the proposals likely overstate the actual scope of the consumption tax base. The experience of most other countries in attempting to tax financial services has led them to exempt such services from a generally applicable consumption tax.

\section{International Implications of Replacing The Income TaX}

\section{A. Mixture of Taxes}

The most radical feature of each of the tax reform proposals is repeal of the federal income tax and replacement with a consumption tax. ${ }^{139}$ All the OECD countries, except the United States and Australia have national-level general consumption taxes, in the form of creditinvoice VATs, as do approximately 75 other countries around the world. No other OECD country has abolished its income tax at the personal or

139. Of course, many of the individual states already have general consumption taxes that raise significant amounts of revenue at the state level. 
corporate level. ${ }^{140}$

Most OECD countries, particularly those in Europe, rely to a greater extent on consumption taxes as a percentage of total tax revenue than does the United States. Japan is a notable exception, relying even less on consumption taxes than does the United States. ${ }^{141}$ It should be noted, however, that the European OECD countries' tax revenues represent a higher percentage of GDP overall than that of the United States: in 1992, the total U.S. tax burden, including federal, state and local taxes, comprised approximately $29.4 \%$ of GDP, while the OECD average was $38.8 \%$, and the European average was even higher. As a result, the OECD average tax burden, including federal, state and local taxes, arising from corporate and personal income taxes was comparable as a percentage of GDP, and even slightly higher, than that in the United States, where $41.5 \%$ of tax revenue, or approximately $12.2 \%$ of GDP, was raised by the income tax. ${ }^{142}$

International practice, then, is to rely on a mixture of income and consumption-based taxes. The international economic and legal effects of eliminating the income tax are untested. The impact of this elimination is likely to be greater, though uncertain in kind, than any differential that might arise from choosing between destination-based and originbased consumption taxes. ${ }^{143}$

The following section considers how the tax proposals would affect the relative taxation of direct investment in the United States or overseas by United States and foreign multinationals. Subsequent sections con-

140. Most, however, have adopted systems to fully or partially integrate the corporate income tax with the personal tax, eliminating or mitigating the two levels of corporate income taxation present in the U.S. "classical" system. While this reduces tax on capital income invested in corporate form, it does not eliminate the "double taxation" of income from capital (that is, the taxation of saved income and the capital income earned with respect to invested capital saved), which could be achieved by taxing a consumption rather than an income base.

141. See Summers, supra note 73 , at 1798 . In 1992, approximately $15 \%$ of aggregate U.S. tax receipts were from general consumption taxes or taxes on specific goods. This contrasts with $28.6 \%$ for all OECD countries. Japan's general consumption and specific goods taxes comprised $12.3 \%$ of its aggregate tax receipts. See Revenue Statistics of OECD Member Countries, 19651993, Organization for Economic Co-Operation and Development (1994), reprinted in JoINT Comm. Proposals to Replace the Income Tax, supra note 6, at 130-31 [hereinafter Revenue Statistics].

142. See id. at 130. On January 23, 1997, German Finance Minister Theo Waigel announced a tax reform proposal that would reduce individual and corporate income tax by U.S. $\$ 27$ billion and increase VAT by U.S. $\$ 8.5$ to $\$ 9$ billion over three years. See David G. Small \& Ulrich E. Michaelis, German Finance Minister Announces Tax Reform Proposal, 14 TAX NotEs INT'L 473 (Feb. 10, 1997). In 1992, Germany's reliance on personal and corporate income taxes, consumption taxes, and taxes on specific goods was below the OECD average, but its social security taxes were substantially above the OECD average. See Revenue Statistics, supra note 141 , at 131 .

143. See Grubert \& Newlon, supra note 18, at 624. 
sider the effects of proposed tax reform on relative taxation of portfolio investment and individuals, as well as possible responses by foreign countries to adoption of a consumption tax by the United States as its primary tax base. ${ }^{144}$

\section{B. Direct Investment}

1. DOMESTIC VERSUS FOREIGN INVESTMENT BY U.S.-BASED MULTINATIONALS

Under current law, most active business income earned by foreign subsidiaries is not taxed by the United States until it is paid to the U.S. shareholder as a dividend. This is referred to as "deferral." Although the current income tax code has many "anti-deferral" provisions, U.S. multinational corporations retain substantial earnings in foreign subsidiaries. The extent to which deferral is beneficial, however, depends on the relative effective corporate-level tax on income from the new investment in the foreign country as compared with the same investment in the United States. One effect of replacing the income tax with a consumption tax may be to decrease the advantage of locating a new investment in a foreign country with a lower effective income tax rate. ${ }^{145}$

Under current law, a foreign tax credit is allowed for foreign income taxes. ${ }^{146}$ Generally, the amount of the credit is limited to the amount of U.S. tax on the same category of foreign income as that on which the foreign tax is paid. A taxpayer may "cross-credit" excess foreign taxes paid to one country against U.S. tax paid on foreign income from another country, so long as the income is in the same category. ${ }^{147}$ As a result of cross-crediting, it may be tax-efficient to generate foreign rather than domestic income. This issue would not arise if the income tax were replaced with a consumption tax.

An issue raised by the tax reform proposals is the extent to which taxation thereunder would affect locational decisions. To the extent that these taxes would be imposed on individuals rather than businesses, in theory, the taxes should not affect locational decisions. In such case, only the non-U.S. income tax systems would be relevant. The incidence of taxation is notoriously difficult to determine, however, and it is probably not possible to reach a clear conclusion regarding the incidence of

144. For thorough discussions of these issues, see Reuven S. Avi-Yonah, The International Implications of Tax Reform, 69 TAX Notes 913 (Nov. 13, 1995); Grubert \& Newlon, supra note 18, at 621; HiNes, supra note 1.

145. Grubert and Newlon demonstrate that a reduced differential between U.S. and low foreign effective tax rates would decrease the incentive for U.S. multinationals to shift investments to low tax rate countries. See Grubert \& Newlon, supra note 18, at 624-26.

146. See I.R.C. \$ 901 (1989).

147. See id. \& 904 . 
either the USA or the Flat Tax. Moreover, in considering the possible effect of these proposals on locational decisions, the effective tax rate under the proposals can vary substantially, depending upon the amount of wages in the business' cost structure, the degree to which the business exports, and the nature of transition relief given to prior investment. ${ }^{148}$

Under the proposed changes, the United States would be the only major developed country to rely principally on a consumption tax and not potentially subject foreign business income to an income tax. ${ }^{149}$ Even with substantially reduced U.S. tax rates, an incentive may remain in certain cases to locate investment outside the United States in order to take advantage of the territorial nature of the consumption tax base. Under an origin-based system, for example, imports would not be taxed and there could be an advantage to locating production in a low-tax foreign country. As discussed above, under a destination-based system, it would be difficult to collect a tax on services from outside the United States.

Taxpayers, however, would not remain idle after tax reform. Because foreign interest income would not be taxed to U.S. businesses, there would be an incentive for U.S. businesses to capitalize their foreign subsidiaries with debt. The interest would be deductible against the foreign income tax and excluded from U.S. business taxation as a return on investment. The interest would reduce the effective foreign tax rate and potentially make a broader range of foreign locations attractive from an after-tax perspective. ${ }^{150}$ Indeed, depending on the sophistication of the foreign income tax system, it might be possible to achieve a "negative" tax rate on new foreign investment.

The positions of a U.S. investor under current income tax rules and post-U.S. tax reform are summarized in Table 1, below:

148. See Sullivan, supra note 13, at 133-34.

149. Some foreign countries exempt foreign dividends from substantial holdings (i.e., greater than five percent of an issuer) and foreign business income that has been subject to taxation in the source country. This is generally referred to as a "territorial" or "exemption" system of foreign income taxation. Interest is generally not exempt from residence country income taxation under either a foreign tax credit or exemption system.

150. Depending on dividend withholding rates, it could be advantageous to incur additional debt through otherwise profitable foreign subsidiaries and distribute the proceeds to the U.S. parent company. 


\section{Table 1}

U.S. Outbound Direct Equity Investment Current Tax Rules

\begin{tabular}{|c|c|c|}
\hline & U.S. Tax Rules & Assumed Country A Tax Rules \\
\hline U.S. investor & $\begin{array}{l}\text { Worldwide taxation, with foreign } \\
\text { tax credit, deferral for active } \\
\text { business income of foreign } \\
\text { subsidiary }\end{array}$ & $\begin{array}{l}\text { Corporate-level income tax } \\
\text { (classical or integration system), } \\
\text { no deduction for distribution, 30\% } \\
\text { source withholding or branch tax } \\
\text { Treaty: Reduces source } \\
\text { withholding and branch tax to 5\% } \\
\text { (partial refund of imputation credit } \\
\text { from some integration countries) }\end{array}$ \\
\hline
\end{tabular}

Post-Tax Reform - No Change in Treaty

\begin{tabular}{l|l|l|}
\multicolumn{1}{l|}{ U.S. Tax Rules } & \multicolumn{1}{l}{ Assumed Country A Tax Rules } \\
\cline { 3 - 4 } U.S. investor & Exemption of non-U.S. income & $\begin{array}{l}\text { Corporate-level income tax } \\
\text { (classical or integration system), } \\
\text { no deduction for distribution, 30\% } \\
\text { source withholding or branch tax }\end{array}$ \\
& $\begin{array}{l}\text { Treaty: Reduces source } \\
\text { withholding and branch tax to 5\% } \\
\text { (partial refund of imputation credit } \\
\text { from some integration countries) }\end{array}$ \\
\hline
\end{tabular}

As Table 1 indicates, the good news for taxpayers about the tax reform proposals is that they are fundamentally territorial and would exempt foreign income. The bad news is that foreign governments would still impose taxes on business income. The United States, however, would only tax value added. Notwithstanding possible behavioral responses by taxpayers, it seems clear from a tax perspective that the United States would be substantially more attractive for new capital investment by U.S. investors after adoption of any of the three tax reform proposals than it is under the current system. It is unclear how foreign governments would respond to the change in U.S. tax policies, however. Some possible responses are discussed below.

The preceding discussion of the relative taxation of direct investment under pre- and post-tax reform should be viewed in a broader economic context, however, than solely with reference to taxes. It is unclear, for example, how the proposed changes would affect savings, interest rates and, in turn, relative exchange rates.

\section{FOREIGN MULTINATIONAL INVESTMENT IN THE UNITED STATES}

Tax reform proponents presumably hope that foreign capital will be drawn to the United States by lower effective tax rates on business activ- 
ity. As is the case with the location of investment by U.S. and multinational firms, however, the issue revolves around the relationship of the effective rates of U.S. and home country tax, as well as the aforementioned effects of interest and currency exchange rates. Although the U.S. tax burden on business would decrease because U.S. investment would be expensed for U.S. tax purposes, there would be no deduction for interest. There would also be no U.S. withholding tax on interest or dividends paid to foreign corporations. If the effective rate of U.S. tax were lower than in alternative non-U.S. locations, a foreign multinational presumably would have an incentive to shift investment to the United States. The precise magnitude of the incentive is uncertain, though, because of the effects of adjustable exchange rates, among other factors.

Another important factor is how the foreign country taxes income earned in the United States. If the foreign country taxes worldwide income subject to a foreign tax credit, there would be a question as to whether it would allow a credit for the U.S. tax. Generally, foreign tax credits are allowed for income, but not consumption, taxes. In theory, a foreign tax credit should only operate to mitigate double taxation. ${ }^{151}$ Because the tax bases under each of these proposals exclude returns to capital, none of the proposed taxes would be considered an "income tax" and likely would not be creditable. One way to address this question would be to ask whether the United States should credit other countries' consumption taxes against its own income tax. Under current law and policy, such a tax is not creditable. ${ }^{152}$ A comparable question is whether a foreign country that taxes on a territorial basis, by exempting income earned through a permanent establishment that is subject to foreign tax or by granting a participation exemption with respect to foreign dividends, would accord such treatment to U.S. investment in the absence of an income tax. In each case, it seems reasonably clear that relief for the U.S. tax would not be granted for purposes of the foreign income tax. The positions of a foreign investor under current tax rules and post U.S. tax reform are summarized in Table 2, below:

151. An argument may be made to allow a credit for the portion of an origin-based consumption tax imposed on "supernormal" returns on investment. See Grubert \& Newlon, supra note 18 , at 627 .

152. For an argument that the United States should credit all foreign taxes, regardless of whether the foreign tax base is income, with a per country foreign tax credit limitation, see Joseph Isenbergh, The Foreign Tax Credit: Royalties, Subsidies, and Creditable Taxes, 39 TAx L. REv. 227 (1984). 
Table 2

Inbound Direct Equity Investment

Current Tax Rules

\begin{tabular}{l|l|l|}
\multicolumn{1}{c}{ U.S. } & \multicolumn{2}{l}{ Country A } \\
investor & $\begin{array}{l}\text { Corporate-level income tax, no } \\
\text { deduction for distribution, 30\% } \\
\text { source withholding or branch tax }\end{array}$ & $\begin{array}{l}\text { Worldwide taxation with credit or } \\
\text { participation exemption, deferral } \\
\text { of taxation for trading income of } \\
\text { subsidiaries or non-tax haven } \\
\text { subsidiaries }\end{array}$ \\
$\begin{array}{l}\text { Treaty: Reduces source } \\
\text { withholding or branch tax to 5\% }\end{array}$ & \\
\hline
\end{tabular}

Post-Tax Reform - No Change in Treaty

\begin{tabular}{l|l|l|}
$\begin{array}{l}\text { Country A } \\
\text { investor }\end{array}$ & $\begin{array}{l}\text { Corporate-level tax on value- } \\
\text { added, no interest deduction, no } \\
\text { source withholding }\end{array}$ & $\begin{array}{l}\text { Worldwide taxation with credit or } \\
\text { participation exemption (but would } \\
\text { credit or exemption be allowed } \\
\text { with respect to a consumption, not } \\
\text { an income tax), deferral of } \\
\text { taxation for trading income of } \\
\text { non-tax haven subsidiaries }\end{array}$ \\
\hline
\end{tabular}

\section{Transfer Pricing}

After tax reform, both U.S.- and foreign-based multinationals would appear to have an incentive to use transfer pricing to shift income to U.S. affiliates or branches or, more significantly, to low-tax countries, prior to sales into the United States. Under a retail sales tax, income shifted to a U.S. affiliate or tax haven would not affect U.S. tax liability, so long as the retail sale was made at the "full" price to the ultimate customer. As noted above, however, it could be difficult to collect a tax on sales to retail consumers. Similarly, under a destination-based VAT, an import's artificially low cost would be recovered upon resale in the United States.

\section{Portfolio Investment}

Substituting a consumption tax for the income tax would reduce or eliminate taxation of investment income for U.S. individuals. As noted above, none of the tax reform proposals would limit the exemption for dividends, interest, or gains on investment securities to investments in U.S. issuers.

Under current law, investors can generally utilize foreign withholding taxes on passive foreign source income as a foreign tax credit. After tax reform, the withholding tax would be an additional marginal cost, reducing the yield on foreign securities subject to withholding relative to other securities. This is the case today with respect to tax-exempt port- 
folio investors such as pension funds and endowments. Although most international fixed-income investment is not subject to withholding tax, dividends on portfolio equity investment generally are.

Notwithstanding the tax disadvantages of international equity investment for tax-exempt investors, international holdings of taxexempt investors have been increasing in recent years. Withholding taxes do not appear to be a major determinant because they generally are not imposed with respect to gains. If a typical dividend yield is only $3 \%$ and the withholding tax is $30 \%$ (or $15 \%$ under an income tax treaty), the effect of the withholding tax would only be 90 (or 45 ) basis points. This may be relatively small compared with whatever "hurdle" rate is applied to justify a non-U.S. investment in the first instance, or as compared with the perceived advantages of international diversification.

For non-U.S. portfolio investors, the elimination of U.S. withholding taxes would be advantageous. Although, as currently designed, the USA tax on individuals purports to impose withholding tax on fixed or determinable payments it would not be effective. It appears that investments by offshore investment companies, whether corporations or partnerships, would not be subject to U.S. withholding under the USA income tax on individuals, and dividends and interest paid to such entities would not be subject to the USA business tax. ${ }^{153}$ If the foregoing analysis is correct, then there would be no withholding as a practical matter because nonresident individuals, and their bankers, would form entities to make U.S. investments.

If the U.S. withholding tax were effectively repealed, U.S. portfolio investment would become more attractive to a foreign investor who could not otherwise credit the withholding tax. Moreover, there might be an additional incentive for foreign investors to make investments in the United States, if the IRS no longer collected information that could be provided to home country tax authorities regarding income payments. There would also likely be greater use of offshore "tax haven" investment entities.

The relative attractiveness of portfolio investment for U.S. and foreign investors before and after tax reform, are summarized in Table 3:

153. Additionally, it does not appear that a financial intermediation business conducted entirely outside the United States would be subject to the USA business tax under Subchapter G. The USA business tax provides, in any event, that gross profit attributable to financial intermediation services provided outside the United States would be excluded under regulations prescribed by the Secretary. See S. 722, 104th Cong. (1995) (to be codified at I.R.C. $\$ 242$ (c)(2)). 
Table 3

Portfolio Equity Investment Current Tax Rules

\begin{tabular}{|c|c|c|}
\hline & U.S. & Country A \\
\hline U.S. investor & $\begin{array}{l}\text { Residence taxation (except for tax- } \\
\text { exempt) }\end{array}$ & $\begin{array}{l}\text { Corporate-level income tax, no } \\
\text { deduction, } 30 \% \text { source } \\
\text { withholding tax } \\
\text { Treaty: Reduces source } \\
\text { withholding tax to } 15 \%\end{array}$ \\
\hline $\begin{array}{l}\text { Country A } \\
\text { investor }\end{array}$ & $\begin{array}{l}\text { Treaty: Reduces source } \\
\text { withholding tax to } 15 \%\end{array}$ & $\begin{array}{l}\text { Residence taxation (except for tax- } \\
\text { exempt) }\end{array}$ \\
\hline
\end{tabular}

Post-Tax Reform - No Change in Treaty

\begin{tabular}{l|l|l|}
\multicolumn{1}{|l}{ U.S. } & \multicolumn{2}{c}{ Country A } \\
\cline { 3 - 3 } U.S. investor & No residence country taxation & $\begin{array}{l}\text { Corporate-level income tax, no } \\
\text { deduction, 30\% source } \\
\text { withholding tax }\end{array}$ \\
Country A & $\begin{array}{l}\text { Treaty: Reduces source } \\
\text { withholding tax to 15\% }\end{array}$ \\
\cline { 3 - 3 } investor & $\begin{array}{l}\text { No corporate-level tax, no } \\
\text { deduction, no source withholding }\end{array}$ & $\begin{array}{l}\text { Residence taxation (except for tax- } \\
\text { exempt) }\end{array}$ \\
\cline { 2 - 3 } & &
\end{tabular}

\section{E. Individuals}

The tax reform proposals would have varying effects on individuals. The retail sales tax would tax added labor value and profit, but only at the point of final sale. Individuals in the United States could avoid the tax by purchasing and consuming the property outside the United States. ${ }^{154}$

The USA tax would continue to tax the worldwide income of individuals, with a credit for foreign income taxes, but would eliminate the foreign earned income exclusion. Whether a nonresident individual U.S. taxpayer would be better off under this system would depend on his level of income and saving.

The Flat Tax would not tax foreign income. Although this would be more generous than the current $\$ 70,000$ foreign earned income exemption, there would also be a lower tax rate on income earned in the United States than under current law. The relative incentive for wage earners with up to $\$ 70,000$ in earned income to move abroad would be

154. See HiNes, supra note 1 , at 486-89. A purchaser would be liable for the tax if the property or service were used or consumed in the United States. See H.R. 3039, 104th Cong. (1996) (to be codified at I.R.C. $§ 1(c)(2)$ ). 
diminished. Highly compensated individuals who could work in a lowtax country, however, would have an incentive to move.

Under current law, estate and gift taxes provide one of the strongest tax incentives for U.S. citizens to expatriate. The retail sales tax and the Flat Tax would repeal the estate tax.

\section{F. Responses of Foreign Countries to U.S. Tax Reform}

This section considers some of the possible initial responses of U.S. trading partners to U.S. tax reform eliminating the individual and corporate income tax. It will quickly become apparent that there is a distinction between the effects of such responses on new investment, which has locational flexibility, and the effects on existing investment, which has less flexibility to move. The effects of foreign government responses on existing investment may be thought of as another transition cost in adopting one of the tax reform proposals.

\section{NON-TREATY COUNTRIES}

If the U.S. income tax were replaced with a consumption-based tax, the United States would be the only major developed country to use a consumption tax base alone, without a tax on dividend and interest income. As discussed above, U.S. investors would have an incentive to capitalize with debt or otherwise strip foreign subsidiaries of earnings. Foreign countries with significant direct investment from the United States might adopt anti-earnings-stripping rules. In the absence of a treaty, such rules could discriminate against U.S. investors.

Similarly, foreign multinationals might be expected to "park" income in the United States. In response, foreign countries might try to adopt rules similar to the "throwback" rules used by states to treat income not taxed in the source country as taxable currently in the country of residence. Even if foreign countries did not go so far as to adopt anti-deferral rules, they would likely deny a credit or exemption for U.S. income.

\section{TREATY COUNTRIES}

The effective elimination of residence taxation on interest, dividends, and gains on sales of securities, and the practical elimination of withholding taxes on interest and dividends, would fundamentally alter the reciprocity of U.S. bilateral income tax treaties. Initially, one wonders why a treaty partner would continue to provide relief from its withholding tax at source if the United States did not tax the income in question.

The response would depend on the treaty partner's relative interest 
in attracting U.S. investment versus obtaining tax revenue. From the perspective of some developing countries, the tax reform proposals may at first seem preferable to the current situation. Developing countries frequently argue that, because the United States taxes worldwide income and allows a foreign tax credit, their withholding tax relief benefits the U.S. Treasury instead of the investor. Under the tax reform proposals, a U.S. multinational investor would benefit directly from withholding tax reductions. Alternatively, if the treaty partner viewed the purpose of the treaty provisions for withholding relief as solely to eliminate double taxation, that country could increase its withholding taxes by terminating its income tax treaty with the United States and suffer little or no detriment. On further consideration, however, developing countries (and perhaps developed countries as well) may be concerned about the favorable taxation of U.S. investment under the reform proposals. This may create pressure to moderate their income taxation of direct investment income.

The pressure to terminate an income tax treaty with the United States might be exacerbated by the potential for tax arbitrage between a U.S. tax system that does not tax income from capital and a treaty partner's income tax system that allows a deduction for interest. As discussed above, interest income effectively would not be taxed by the United States, so there would be an incentive for U.S. taxpayers to debt capitalize foreign investment; thus, interest would be deductible against the foreign income tax and excluded from U.S. taxation as a return on investment. Although incentives to use debt capitalization already exist, often in the form of a "hybrid" instrument treated as equity for U.S. purposes, fundamental tax reform could increase these pressures. This in turn could increase pressure on foreign countries to preserve their income tax bases. One way to do this with respect to U.S. investment would be to terminate its income tax treaty with the United States, thereby imposing high statutory withholding taxes on payments of interest and dividends to U.S. residents. Terminating the treaty would be a more direct tool for restricting "earnings stripping" or "base erosion" by U.S. investors than would adoption of legislation that would apply to investors from all countries. It would also be less offensive than would adopting legislation that discriminates against U.S. investment.

To forestall such treaty terminations, Congress could provide for imposition of a discriminatory withholding tax on interest and dividend payments to non-U.S. individuals and businesses. If such a withholding tax were adopted, one issue that would arise is whether a nondiscrimination treaty clause would prohibit imposition of income tax on investment income, collected by withholding, on non-U.S. persons resident in the treaty partner country, when the United States does not tax such income 
to its own residents. ${ }^{155}$ If existing treaties were observed, the United States would be exchanging an exemption from its discriminatory withholding tax for mere reductions in the treaty partner's withholding tax. It is conceivable that the United States would unilaterally condition its reduction of newly-enacted withholding taxes on the treaty partner's reciprocally exempting U.S. residents from withholding tax, as suggested in the USA tax proposal. ${ }^{156}$ Quaere whether this would be attractive to U.S. treaty partners having relatively reciprocal trade with the United States and a significant income tax base.

Even assuming that the United States would give effect to a treaty nondiscrimination article preventing it from applying its withholding tax, for reasons described above, a treaty partner still might consider it advantageous to terminate its treaty with the United States. If a foreign country did terminate its treaty with the United States, its withholding taxes would increase to domestic statutory rates, which typically are $25 \%$ or more. The effect would be much more significant if the foreign country also taxed capital gains of nonresidents. ${ }^{157}$ This would substantially increase foreign taxation of existing U.S. investment abroad, but would discourage new investment.

The foregoing discussion suggests that substitution of a consumption tax for an income tax would likely place pressure on treaty partners to consider terminating their income tax treaties with the United States. Although some countries that import capital from the United States may wish to retain their present treaties, many important treaty partners might either terminate or substantially renegotiate their existing treaties.

The treaty issue is not limited to comprehensive income tax treaties. International shipping and aircraft agreements also generally provide for reciprocal exemption from source country taxation of income from these activities. The parties to these agreements may also reconsider whether it would be in their interest to retain them.

\section{G. Simplification}

There is currently a thirst for a substantial simplification of interna-

155. As Grubert and Newlon point out, treaty nondiscrimination clauses would likely prohibit the imposition of income tax on investment income, collected by withholding, on non-U.S. persons resident in the treaty partner country when the United States does not tax such income to its own residents. See Grubert \& Newlon, supra note 18, at 642.

156. See S. 722, 104th Cong. (1995) (to be codified at I.R.C. $\$ 133$ (c)) (providing a reciprocal exemption for withholding tax on payments to nonresident individuals if the treaty partner is a party to a tax information exchange agreement).

157. For example, if an investor has $\$ 100$ million to invest and requires a $20 \%$ simple return, and a typical dividend return is $3 \%$, the cost of a $30 \%$ dividend withholding tax is $3 \% \times 30 \%=$ $.9 \%$ (or 90 basis points). A $30 \%$ tax on gains would cost $17 \% \times 30 \%=5.1 \%$ (or 510 basis points). 
tional tax rules. Adoption of a consumption tax would do more to simplify the taxation of international activity than any income tax reform because none of the proposals would tax activity outside the United States. Consider the Code rules that would no longer apply: anti-deferral regimes of subpart $F$; foreign personal holding companies; passive foreign investment companies; foreign investment companies accumulated earnings tax and sections 367 and 1491; foreign tax credit rules; and foreign sales corporation rules.

Although simplification of the international tax rules is a significant potential benefit of fundamental tax reform, the simplification results from eliminating the tax on income from capital. Shifting the tax base to a consumption tax has implications transcending simplification of the international tax rules.

\section{Conclusions}

We have discussed some of the reasons why the tax reform proposals diverge from international practice. The principal reason, at least in the cases of the USA tax and the Flat Tax, ultimately relates to the accompanying elimination of the income tax. The proposals' features which seek to preserve progressivity-the USA tax's business credit for the payroll tax and the Flat Tax's business tax deduction for wagesraise questions about consistency with GATT in the case of the USA tax and may require an origin-based tax in the case of the Flat Tax. The retail sales tax, which does not address the regressivity issue to the same extent, is border adjustable and pure from a GATT perspective. Notwithstanding the reasons for the proposals' divergence from existing international practice, a credit-invoice VAT should be given equal consideration.

The case for use of the destination principle is not as strong as is commonly claimed. The rationale that the destination principle would serve as an incentive for exports and would also be protectionist does not withstand scrutiny. The fact that an international consensus exists favoring the destination principle, the relative certainty of its treatment under GATT, and sectoral effects are the principal reasons favoring adoption of the destination principle in a U.S. consumption tax.

An examination of the difficulties in taxing cross-border provision of services, including financial services, demonstrates that there are significant administration and enforcement issues to be resolved in implementing a comprehensive consumption tax.

The most significant international aspect of the tax reform proposals is replacement of the income tax with a consumption tax. A consumption tax, whether designed to implement the destination or the 
origin principle, is fundamentally territorial in reach. This has substantial implications for the relationship of the U.S. tax system with that of its trading partners, and would likely place substantial pressure on U.S. income tax treaty partners to terminate such treaties with the United States. Although this would be detrimental to existing foreign direct investment by U.S. investors, it is but one of many "costs" of tax reform that must be weighed against the potential benefits.

This review of some of the international issues presented by the tax reform proposals raises further questions as to whether the degree of change proposed is worth the benefits to be achieved. 